\title{
The Atypical Guanine-Nucleotide Exchange Factor, Dock7, Negatively Regulates Schwann Cell Differentiation and Myelination
}

\author{
Junji Yamauchi, ${ }^{1,3,5}$ Yuki Miyamoto, ${ }^{1}$ Hajime Hamasaki, ${ }^{1,3}$ Atsushi Sanbe, ${ }^{1}$ Shinji Kusakawa, ${ }^{1}$ Akane Nakamura, ${ }^{2}$ \\ Hideki Tsumura, ${ }^{2}$ Masahiro Maeda, ${ }^{4}$ Noriko Nemoto, ${ }^{6}$ Katsumasa Kawahara, ${ }^{5}$ Tomohiro Torii, ${ }^{1}$ and Akito Tanoue ${ }^{1}$ \\ ${ }^{1}$ Department of Pharmacology and ${ }^{2}$ Laboratory Animal Resource Facility, National Research Institute for Child Health and Development, Setagaya, Tokyo \\ 157-8535, Japan, ${ }^{3}$ Department of Biological Sciences, Tokyo Institute of Technology, Midori, Yokohama 226-8501, Japan, ${ }^{4}$ IBL, Ltd., Fujioka, Gumma \\ 375-0005, Japan, and 5Department of Physiology and ${ }^{6}$ Bioimaging Research Center, Kitasato University School of Medicine, Sagamihara, Kanagawa \\ 252-0374, Japan
}

In development of the peripheral nervous system, Schwann cells proliferate, migrate, and ultimately differentiate to form myelin sheath. In all of the myelination stages, Schwann cells continuously undergo morphological changes; however, little is known about their underlying molecular mechanisms. We previously cloned the dock7 gene encoding the atypical Rho family guanine-nucleotide exchange factor (GEF) and reported the positive role of Dock7, the target Rho GTPases Rac/Cdc42, and the downstream c-Jun N-terminal kinase in Schwann cell migration (Yamauchi et al., 2008). We investigated the role of Dock7 in Schwann cell differentiation and myelination. Knockdown of Dock7 by the specific small interfering (si)RNA in primary Schwann cells promotes dibutyryl cAMP-induced morphological differentiation, indicating the negative role of Dock7 in Schwann cell differentiation. It also results in a shorter duration of activation of Rac/Cdc42 and JNK, which is the negative regulator of myelination, and the earlier activation of Rho and Rho-kinase, which is the positive regulator of myelination. To obtain the in vivo evidence, we generated Dock7 short hairpin (sh)RNA transgenic mice. They exhibited a decreased expression of Dock7 in the sciatic nerves and enhanced myelin thickness, consistent with in vitro observation. The effects of the in vivo knockdown on the signals to Rho GTPases are similar to those of the in vitro knockdown. Collectively, the signaling through Dock7 negatively regulates Schwann cell differentiation and the onset of myelination, demonstrating the unexpected role of Dock7 in the interplay between Schwann cell migration and myelination.

\section{Introduction}

The Rac, Cdc42, and Rho subfamilies of Rho GTPases sequentially or antagonistically control many aspects of cell morphological changes and differentiation (Hall, 1998; Hempstead, 2005). All Rho GTPases (21 members in humans) act as molecular switches. Guanine-nucleotide exchange factors (GEFs) catalyze the intrinsically slow exchange reaction of GDP with GTP to generate active GTPases. This reaction is a very important ratelimiting step because GEFs define the timing and strength of

\footnotetext{
Received June 1, 2011; revised July 11, 2011; accepted July 18, 2011.

Author contributions: J.Y. designed research; J.Y., Y.M., H.H., A.S., S.K., N.N., and K.K. performed research; A.N., H.T., M.M., T.T., and A.T. contributed unpublished reagents/analytic tools; J.Y. and T.T. analyzed data; J.Y. wrote the paper.

This work was supported by Grants-in-Aid for Scientific Research from the Japanese Ministry of Education, Culture, Sports, Science, and Technology (22300123 and 23650200 to J.Y.) and the Japanese Ministry of Health, Labor, and Welfare (KHA1001 to J.Y.; 10103478 to J.Y., Y.M., T.T., and A.T.), and by research grants from the Human Sciences Foundation (to J.Y.), the Mochida Foundation (to J.Y.), the Suzuken Memorial Foundation (to J.Y.), and the Takeda Science Foundation (to J.Y.). We thank Drs. E. M. Shooter, Y. Kaziro, and N. Kitamura for their participation in insightful discussions and for providing encouragement. We thank K. Spicer and W. Furmanski for reading this paper. We also thank M. Tsuji for technical advice on splenocyte isolation and M. Hirata for technical advice on sciatic nerve fixation.

Correspondence should be addressed to Dr. Junji Yamauchi, Department of Pharmacology, National Research Institute for Child Health and Development, 2-10-1 Okura, Setagaya, Tokyo 157-8535, Japan. E-mail: jyamauchi@nch.go.jp.

DOI:10.1523/JNEUROSCI.2738-11.2011

Copyright $\odot 2011$ the authors $\quad 0270-6474 / 11 / 3112579-14 \$ 15.00 / 0$
}

GTPase activation by integrating upstream intracellular signals. It is worth noting that in humans, the number of GEFs for Rho GTPases, Dbl family GEFs (Schmidt and Hall, 2002; Rossman et al., 2005), and atypical Dock180-related proteins (Matsuda and Kurata, 1996; Côté and Vuori, 2002, 2007; Meller et al., 2005; Kinchen and Ravichandran, 2007; Miyamoto and Yamauchi, 2010) comes to $\sim 80$ : the fact that this number is much greater than the number of cognate Rho GTPases indicates that GEFs can display tissue-specific and/or developmental stage-specific functions.

During development, Schwann cells in the peripheral nervous system proliferate and migrate along axons to their final destinations, where they eventually ensheath individual axons and form myelin sheaths after birth. The myelin sheath is morphologically differentiated Schwann cell plasma membranes that insulate axons and markedly increase the nerve conduction velocity (Bunge, 1993; Mirsky and Jessen, 1996; Nave and Salzer, 2006). The mechanism by which the myelin sheath is formed is very dynamic and complex, as the surface area of the myelin sheath often grows to $>100$ times larger than the collective surface area of the premyelinating Schwann cell plasma membranes. Evidence indicates that many growth factors and various adhesion molecules, which are presented by sensory neurons such as the dorsal root ganglion (DRG) neurons, bind to their cognate receptors on 
Schwann cells and regulate myelination by Schwann cells. However, less is known about the intracellular signaling mechanism.

In our studies of GEFs for Rho GTPases in Schwann cells (Yamauchi et al., 2003, 2004, 2005a, 2005b), we have isolated the dock7 gene (GenBank Acc. Nos. DQ118679/DQ118680/ DQ309763), one of 11 mammalian genes related to the prototypic dock180 gene. We reported that Schwann cells abundantly express Dock7, and that Dock7, acting through Rac/Cdc42, positively regulates Schwann cell migration before the initiation of myelination (Yamauchi et al., 2008). Here, we report that Dock7 knockdown by small interfering (si)RNA in Schwann cells promotes dibutyryl cAMP-induced morphological differentiation. Dock7 knockdown shortens the duration of Rac/Cdc42 activation and the downstream activation of JNK, whose signaling negatively regulates Schwann cell differentiation and myelination (Parkinson et al., 2004). Early activation of Rho and Rho-kinase, which positively regulates myelination (Melendez-Vasquez et al., 2004), is also observed to the result from Dock7 knockdown. Furthermore, Dock7 short hairpin (sh)RNA transgenic mice exhibit enhanced myelin thickness, decreased Rac/Cdc42/JNK activity, and increased Rho/Rho-kinase activity in sciatic nerves. Thus, signaling through Dock7 negatively regulates Schwann cell differentiation and the onset of myelination, uncovering a previously unknown molecular signaling relationship underlying migration and myelination. To the best of our knowledge, this is the first report of a negative role of a GEF for Rho GTPases in Schwann cell differentiation and myelination.

\section{Materials and Methods}

Antibodies and chemicals. The following antibodies were purchased: antiRac1, anti-Cdc42, and anti-actin from BD Biosciences, PharMingen, and Sigma-Aldrich; anti-RhoA, anti-JNK1, anti-Akt1, anti-Oct6, anti-Krox20, and anti-Sox10 from Santa Cruz Biotechnology; anti-(pThr183/ pTyr185)panJNK, anti-myosin binding subunit (MBS, also called MYPT1/ PPP1R12A), anti-(pT853)MBS, anti-(pS473)Akt1, anti-stathmin, and anti(pS16)stathmin from Cell Signaling Technology; anti-(pY1118)Dock7 from IBL; anti-myelin protein zero (MPZ) from Abnova; anti-myelin basic protein (MBP) from Covance; anti-p75NTR from Promega; anti-neuregulin-1 from Millipore; anti-neurofilament from Sigma-Aldrich; and anti-GFP from Nacalai Tesque and Wako Chemicals. The rabbit serum for Dock7 was generated against a KLYPDGRVRPTRE peptide (synthesized by IWAKI). The polyclonal anti-Dock7 antibody was affinity purified using an antigen peptide-conjugated resin. The following chemicals were purchased: JNK inhibitor I, SP600125, and Y27632 from Enzo Life Sciences; and dibutyryl adenosine $3^{\prime}, 5^{\prime}$-cyclic monophosphate (dibutyryl cAMP) from SigmaAldrich and Nacalai Tesque.

$R T-P C R$. Total RNA was isolated by Trizol (Life Technologies) and used in reverse transcription reactions performed with Superscript III reverse transcriptase (Life Technologies). Thirty cycles of PCR amplification were performed using ExTaq polymerase (Takara), each cycle consisting of denaturation at $94^{\circ} \mathrm{C}$ for $1 \mathrm{~min}$, annealing at $58^{\circ} \mathrm{C}$ for $1 \mathrm{~min}$, and extension at $72^{\circ} \mathrm{C}$ for $1 \mathrm{~min}$. The primers used were as follows: 5'-GAACACCAGGAGGATCCTGAAATGTTG-3' (sense) and 5' -GAGA TCCATTTTGCGAAGGCTCATTCG-3' (antisense) for rat Dock7; 5' GAGAAACTGACTCAAGTCTATAGAACTC-3' (sense) and 5'-TCAT ACTTCAGAGTATCTTGGGGAAC- $3^{\prime}$ (antisense) for rat Dock11; and 5'-ATGGATGACGATATCGCTGCGCTC-3' (sense) and 5' -CTAGAA GCATTTGCGGTGCACGATG-3' (antisense) for $\beta$-actin.

Schwann cell culture, morphological differentiation, proliferation, and migration. Primary Schwann cells were prepared from sciatic nerves of male or female Sprague-Dawley rats or C57BL/6JJmc mice (SLC) on Postnatal Day 1, as described previously (Yamauchi et al., 2003, 2004, 2005a, 2005b, 2008). Briefly, Schwann cells were cultured on poly-Llysine-coated culture dishes in DMEM containing 10\% heat-inactivated FBS and $50 \mu \mathrm{g} / \mathrm{ml}$ gentamicin. Schwann cells were plated for experiments on collagen (type I)-coated culture dishes or wells. For morpho- logical differentiation experiments, rat Schwann cells were cultured, first in Sato medium (Bottenstein and Sato, 1979) for $1 \mathrm{~d}$, and then in Sato medium containing $0,0.3$, or $1 \mathrm{~mm}$ dibutyryl cAMP for an additional $2 \mathrm{~d}$ (Sobue et al., 1986; D’Antonio et al., 2006; Monje et al., 2010). For a proliferation assay, Schwann cells were seeded at $1 \times 10^{5}$ cells $/ 3.5 \mathrm{~cm}$ dish, cultured in the presence of $10 \mathrm{ng} / \mathrm{ml}$ neuregulin-1 (R\&D Systems) and $5 \mu \mathrm{M}$ forskolin for $0-48 \mathrm{~h}$, and counted using a hemocytometer. Cell migration was measured using a 24 well Boyden chamber. In brief, polyethyleneterephthalate ( $8 \mu \mathrm{m}$ pore size) filters were coated with collagen. Schwann cells $\left(1 \times 10^{5}\right.$ cells $)$ in $500 \mu$ l of medium per well were loaded into the upper chambers, which were inserted into the tissue-culture wells containing $20 \mathrm{ng} / \mathrm{ml}$ neuregulin-1 at a final concentration of 10 $\mathrm{ng} / \mathrm{ml}$ in $500 \mu \mathrm{l}$ of medium per well. After incubation at $37^{\circ} \mathrm{C}$ for $6 \mathrm{~h}$, the filters were stained with Giemsa solution. The number of stained, migrating cells at the bottom surface of the filters was counted (Yamauchi et al., 2003). For a migration assay that more closely imitated physiological conditions, Schwann cell reaggregates were used (Yamauchi et al., 2004). The reaggregates were placed onto DRG axons and allowed to migrate in the presence of $10 \mathrm{ng} / \mathrm{ml}$ neuregulin- 1 for $6 \mathrm{~h}$.

siRNA oligonucleotides. The 21 nucleotide siRNA duplexes were synthesized by Eurogentec. The specific target nucleotide sequence for mouse Dock7 was 5'-AAGACGTTCGATGTCAATAGA-3' (Yamauchi et al., 2008). The target sequence of the control Photinus pyralis luciferase siRNA was 5'-AAGCCATTCTATCCTCTAGAG-3', which does not have significant homology to any mammalian gene sequences.

siRNA transfection. Schwann cells were transfected with siRNA oligonucleotides using the Oligofectamine (Life Technologies) or PrimaPort reagent (Wako Chemicals), each according to its manufacturer's instruction. The medium was replaced $24 \mathrm{~h}$ after transfection. To confirm the cell viability under these transfection conditions, cells were stained with $0.4 \%$ trypan blue. Attached trypan blue-incorporating cells made up $<2.5 \%$ of cells in each experiment after $72 \mathrm{~h}$ posttransfection.

Immunofluorescence. Cells on the collagen-coated glass coverslips were fixed in PBS containing 4\% paraformaldehyde and permeabilized with PBS containing $0.1 \%$ Tween-20. Permeabilized cells were blocked and incubated first with primary antibodies and then with fluorescencelabeled secondary antibodies. The glass coverslips were mounted with the Vectashield reagent (Vector Laboratories). The fluorescent images were captured using an Eclipse TE-300 microscope system (Nikon) and AxioVision software (Carl Zeiss) or a DMI4000 microscope system (Leica) and AF6000 imaging software (Leica).

$D R G$ neuronal culture. DRG neurons were dissociated from male or female rat or mouse embryos on Gestational Day 13, purified, and cultured on collagen-coated culture dishes in DMEM containing 10\% heatinactivated FBS and $100 \mathrm{ng} / \mathrm{ml}$ NGF (Yamauchi et al., 2004). For morphological analysis, mouse DRG neurons were cultured for $2 \mathrm{~d}$ after DRG dissociation, fixed with $4 \%$ paraformaldehyde, stained with an anti-neurofilament antibody, and observed using the fluorescencemicroscope system.

Cell line culture and plasmid transfection. 293T cells were cultured in DMEM containing $10 \%$ heat-inactivated FBS, $50 \mathrm{U} / \mathrm{ml}$ penicillin, and 50 $\mu \mathrm{g} / \mathrm{ml}$ streptomycin. Cells were transfected using the CalPhos transfection kit (Takara) according to the manufacturer's instructions.

Immunoprecipitation and immunoblotting. Cells were lysed in lysis buffer A (50 mм HEPES-NaOH pH 7.5, 20 mm $\mathrm{MgCl}_{2}, 150 \mathrm{~mm} \mathrm{NaCl}, 1 \mathrm{~mm}$ dithiothreitol, $1 \mathrm{~mm}$ phenylmethane sulfonylfluoride, $1 \mu \mathrm{g} / \mathrm{ml}$ leupeptin, $1 \mathrm{~mm}$ EDTA, $1 \mathrm{~mm} \mathrm{Na} \mathrm{VO}_{4}, 10 \mathrm{~mm} \mathrm{NaF}$, and $0.5 \% \mathrm{NP}-40$ ) or lysis buffer A with 1\% CHAPS and 0.3\% SDS (Yamauchi et al., 2001; Miyamoto et al., 2006). The proteins in the centrifugally cleaned supernatants were mixed with resin (Santa Cruz Biotechnology) that was preabsorbed with antibodies. The washed immunoprecipitates or the proteins in the cell lysates were denatured and then subjected to SDS-PAGE. The electrophoretically separated proteins were transferred to PVDF membranes, blocked, and immunoblotted first with primary antibodies and then with peroxidase-conjugated secondary antibodies. The bound antibodies were detected by chemiluminescence. The band intensities in each immunoblot and their backgrounds were analyzed with UN-SCAN-IT software (Silk Scientific). The band intensities were subtracted from their backgrounds. 

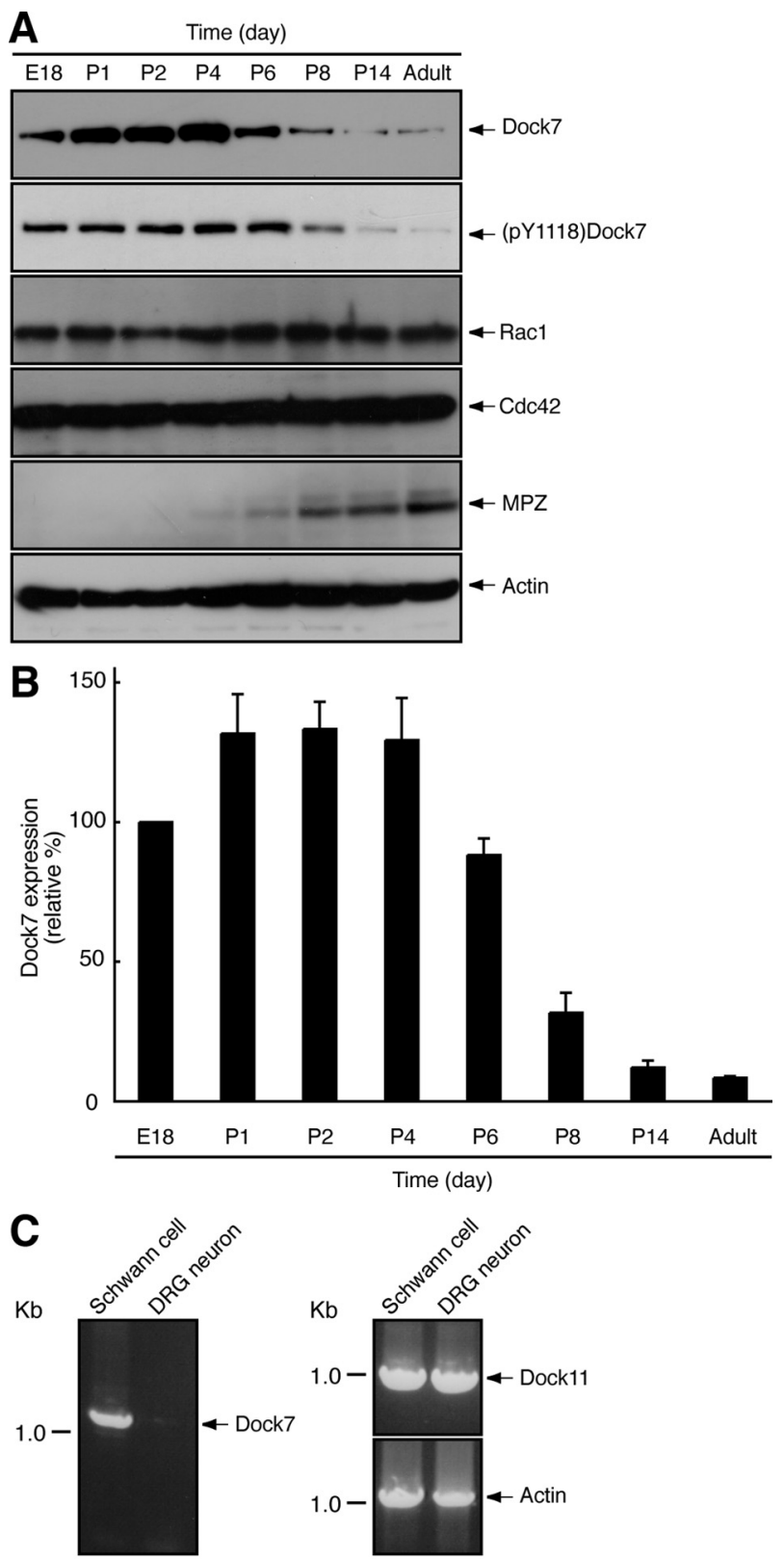

D Treated with Treated with

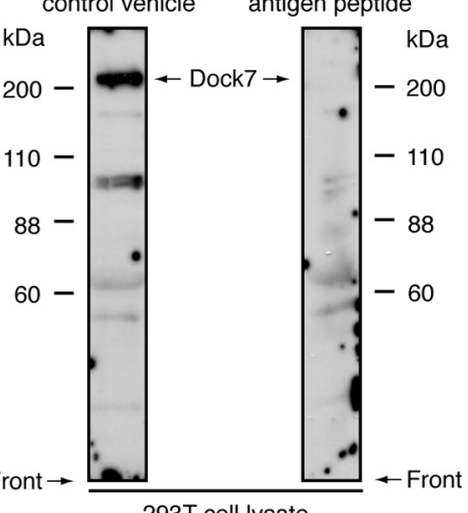

Figure 1. Dock7 is downregulated following sciatic nerve development. $A$, Tissue extracts were prepared from rat sciatic nerves on Embryonic Day 18 (E18) or Postnatal Day 1-14 (P1P14), or upon adulthood, subjected to SDS-PAGE, transferred to PVDF membranes, and immunoblotted with an antibody against Dock7, (pY1118)Dock7, Rho GTPases Rac1/Cdc42, the
Affinity precipitation for active Rho GTPases. Recombinant GST-tagged CRIB (active, GTP-bound Racl and Cdc42-binding domain of Pak1) and RBD (active, GTP-bound RhoA-binding domain of mDia1) were produced using Escherichia coli BL21 (DE3) pLysS and purified. Briefly, E. coli cells were treated with $0.4 \mathrm{~mm}$ isopropyl-1-thio- $\beta$-Dgalactopyranoside at $30^{\circ} \mathrm{C}$ for $2.5 \mathrm{~h}$. Unless otherwise indicated, all steps were performed at $4^{\circ} \mathrm{C}$. E. coli cells were harvested by centrifugation and a cell-free extract was made by the addition of $500 \mu \mathrm{g} / \mathrm{ml}$ lysozyme and $100 \mu \mathrm{g} / \mathrm{ml}$ DNase I in lysis buffer B (50 mM Tris- $\mathrm{HCl} \mathrm{pH} \mathrm{7.5,} 5 \mathrm{~mm}$ $\mathrm{MgCl}_{2}, 1 \mathrm{~mm}$ dithiothreitol, $1 \mathrm{~mm}$ phenylmethane sulfonylfluoride, 1 $\mu \mathrm{g} / \mathrm{ml}$ leupeptin, $1 \mathrm{~mm}$ EDTA, and $0.5 \% \mathrm{NP}-40$ ). The lysates were centrifuged and the supernatants were mixed with glutathione resin. The bound protein was washed with lysis buffer B and eluted with lysis buffer B containing $20 \mathrm{~mm}$ glutathione. The buffer contained in elution fractions was exchanged by dialyzing against a reaction buffer $(20 \mathrm{mM}$ HEPES-NaOH pH 7.5, $150 \mathrm{~mm} \mathrm{NaCl}, 5 \mathrm{~mm} \mathrm{MgCl}_{2}, 1$ mm dithiothreitol, $1 \mathrm{~mm}$ phenylmethane sulfonylfluoride, $1 \mu \mathrm{g} / \mathrm{ml}$ leupeptin, and $1 \mathrm{mM}$ EDTA), and the aliquots were stored at $-80^{\circ} \mathrm{C}$ until use. To detect active Rac1/Cdc42 or RhoA in the cell lysates, affinity precipitation was performed using GST-CRIB or GST-RBD, respectively (Yamauchi et al., 2001; Miyamoto et al., 2006). Each affinity precipitated Rho GTPase was detected through immunoblotting with its anti-Rho GTPase antibody.

Generation of Dock7 shRNA transgenic mice. First, the tandem units, namely, simian virus SV40 enhancer; artificial ferritin composite promoter, which combines human ferritin heavy chain FerH promoter with mouse elongation factor EF1 promoter; EGFP; and mouse EF1 polyadenylation signal were amplified using the mouse in vivo expression vector pVIVO2-GFP/LacZ (4982-9620 bases; InvivoGen) as the template and digested by the EcoRI and BamHI restriction enzymes. Second, the mouse shRNA transcription vector pSINsimU6 (1294-3944 bases; Takara), which was inserted with ShDock7 oligonucleotide (sense oligonucleotide: 5'-GATCCGACGTTCGATGTCAATAGATAGTGCTCCTGG TTGTCTATTGACATCGAACGTCTTTTTTAT-3'; antisense oligonucleotide: 5'-CGATAAAAAA GACGTTCGATGTCAATAGACAACCAGGAGC ACTATCTATTGACATCGAACGTAG-3'), was digested by EcoRI. They were successively ligated into the EcoRI and BamHI sites of a pCMV5 backbone as the subcloning vector. DNA oligonucleotide synthesis and sequencing were performed by the DNA service of Fasmac. The DNA fragment $(\sim 6.2 \mathrm{~kb})$ containing EGFP and ShDock7 was digested from the vector backbone by NcoI, purified, and injected into fertilized BDF1 oocytes. Transgenic founders were mated to wild-type C57BL/6JJmc and the transgene was stably maintained for at least eight generations. Male mice were used for experiments if it was possible to distinguish their sex. The transgenic mice appeared healthy and normally bred. Identification of transgenic founder mice and transgenic mice was determined by PCR on DNA prepared from tail biopsies (EGFP primer pair: $5^{\prime}$-CAATCATGAGCAAGGG AGAAGAACTCTTTACTGGTGTTGTC- ${ }^{\prime}$ ' and $5^{\prime}$-TTTACTTGTACAGC TCATCCATTCCCAGAGTAATTCCTGC-3'; and U6 primer pair: 5'-CG CACAGACTTGTGGGAGAAGCTCGGCTACTC- ${ }^{\prime}$ and $5^{\prime}$-GCTTTGCA TACTTCTGCCTGCTGGGGAGCCTG-3'). The primer pair for Oct $3 / 4$ as the positive control was $5^{\prime}$-CCGGGATCCAAGCTTTGTGAACTTGGCG GCTTCCAAGTCG- $3^{\prime}$ and $5^{\prime}$-CCGGGATCCCATTACTGGCCTGGTGC TTAGTTATCTTTG-3'. PCR was performed for 30 cycles, each consisting of denaturation at $94^{\circ} \mathrm{C}$ for $1 \mathrm{~min}$, annealing at $65^{\circ} \mathrm{C}$ for $1 \mathrm{~min}$, and extension at $72^{\circ} \mathrm{C}$ for $1 \mathrm{~min}$.

myelin marker protein $\mathrm{MPZ}$, or actin (as a control). $\boldsymbol{B}$, The band intensities of an immunoblot with an anti-(pY1118)Dock7 antibody are shown as the relative intensities $(n=3)$. C, RT-PCR analysis shows that Dock7 mRNA is abundantly present in primary Schwann cells and very weakly present in primary DRG neuronal cells. RT-PCR analysis for $\beta$-actin and Dock11 was performed as the control. $\boldsymbol{D}$, 293T cell lysates were immunoblotted with an antibody against a KLYPDGRVRPTRE peptide consensus in rat, mouse, and human Dock7 in the presence of an antigen peptide (right panel) or with an antibody in a control vehicle (left panel). In 293T cells, this antibody primarily recognizes $>200 \mathrm{kDa}$ of the full-length Dock7, which disappears in response to the treatment with antigen peptide. The lower bands $(88-110 \mathrm{kDa})$ may correspond to the alternatively spliced variant of Dock7 (GenBank Acc. No. DQ309763) and/or may be degradation products of Dock7. Data were evaluated using one-way ANOVA ( ${ }^{*} p<0.01$ ). 

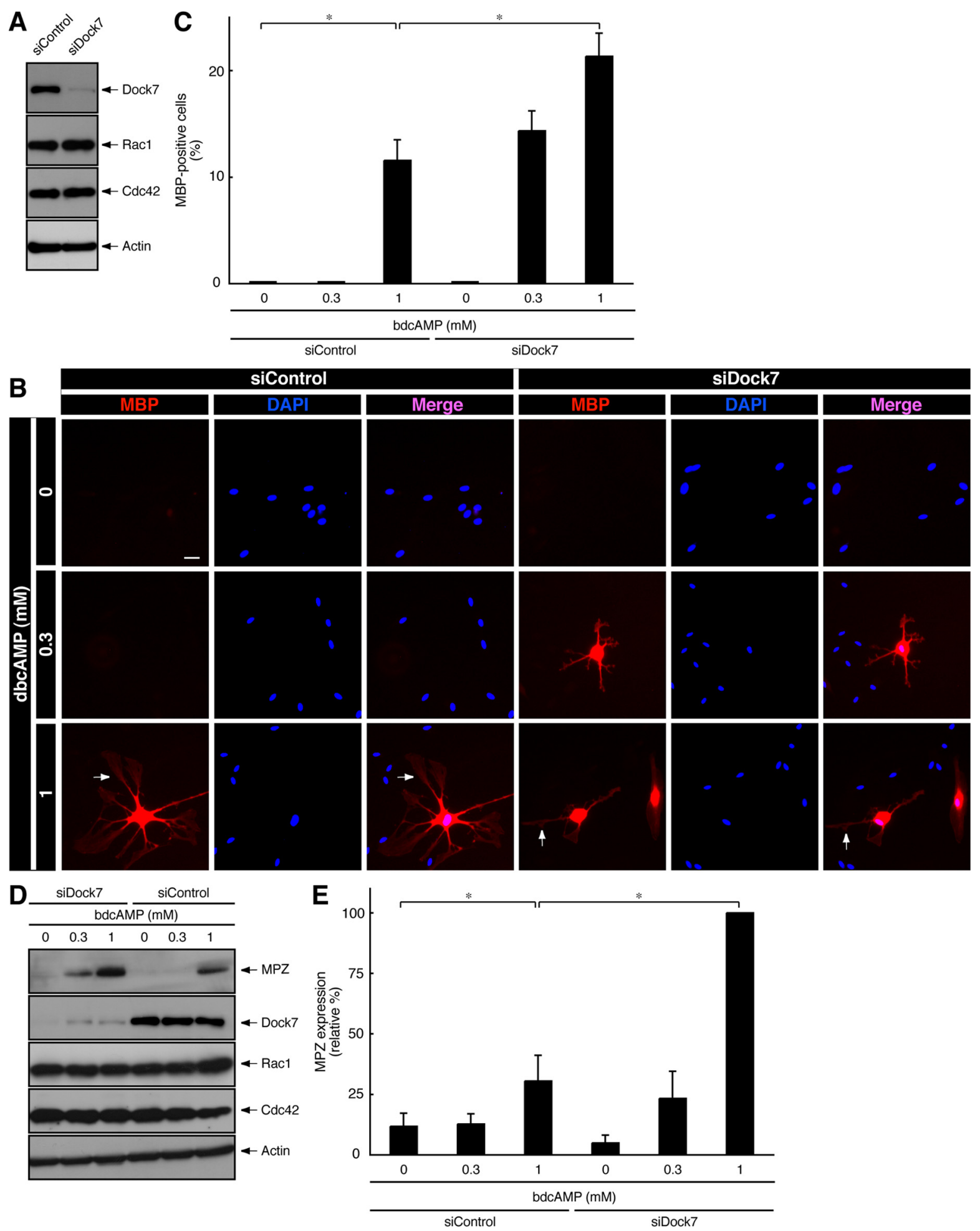

Figure 2. Dock7 knockdown promotes dibutyryl cAMP-induced morphological differentiation. $A$, Rat primary Schwann cells were transfected with siRNA for Dock7 or control luciferase, lysed, and immunoblotted with an antibody against Dock7, Rac1, Cdc42, or actin. B, Dock7 or luciferase siRNA-transfected Schwann cells were treated with 0, 0.3, or 1 mm dibutyryl cAMP for 2 d. Immunostaining with an anti-MBP antibody (red) and nuclear DAPI (blue) staining were performed. MBP-positive cells exhibit more flattened shapes with extending branched processes. Scale bar, $30 \mu \mathrm{m}$. The arrow indicates a myelin web-like structure with fenestrated cytoplasmic sheets. C, The percentages of MBP-expressing, morphologically differentiated Schwann cells were calculated $(n=4)$. D, Schwann cells transfected with Dock7 or luciferase siRNA were treated with $0-1 \mathrm{~mm}$ dibutyryl cAMP for $2 \mathrm{~d}$, lysed, and immunoblotted with an antibody against MPZ, Dock7, Rac1, Cdc42, or actin. $\boldsymbol{E}$, The band intensities for MPZ are shown as the relative intensities $(n=4)$. Data were evaluated using one-way ANOVA ( $\left.{ }^{*} p<0.01\right)$.

Chromosome preparation and fluorescence in situ hybridization. Chromosome preparation, replication R-banding, and FISH mapping were performed according to the method of Matsuda and Chapman (1995). Briefly, transgenic mouse splenocytes were synchronized by thymidine blockage for $16 \mathrm{~h}$, treated with 5-bromo-2'-deoxyuridine for an additional $5.5 \mathrm{~h}$ after the release of excessive thymidine, and harvested after $0.5 \mathrm{~h}$ of Colcemid treatment. The plasmid DNAs were labeled with Cy3dUTP for use as probes. After hybridization, the slides were washed first 
$\mathbf{A}$

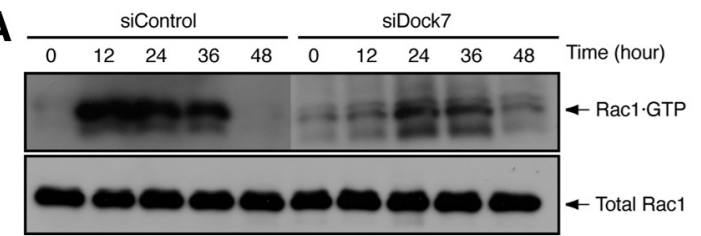

C

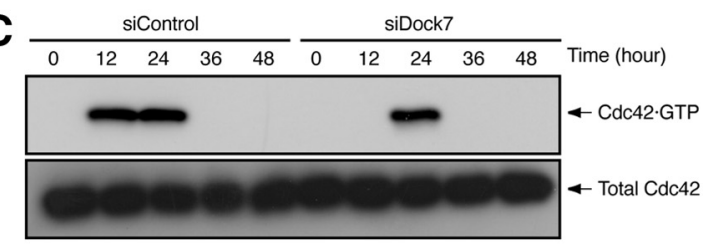

$\mathbf{E}$

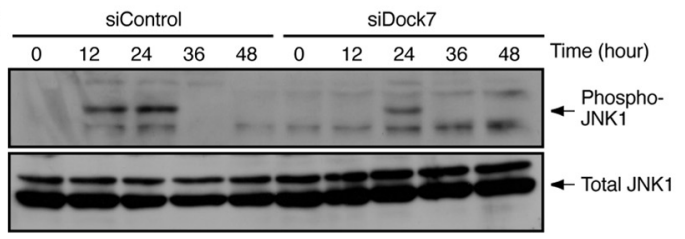

G
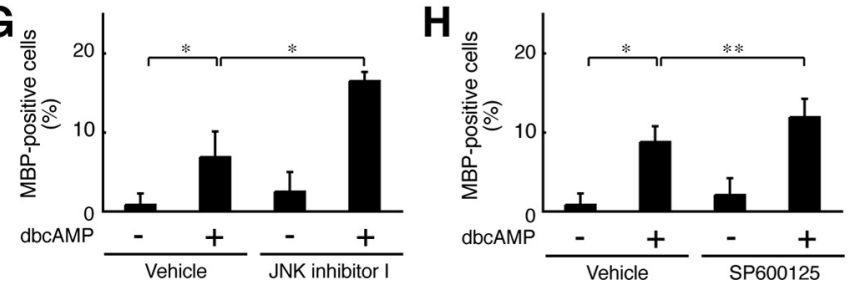

Figure 3. Dock7 knockdown changes Rac1/Cdc42/JNK signaling in Schwann cells. $\boldsymbol{A}-\boldsymbol{D}$, Dock7 or luciferase siRNA-transfected Schwann cells were collected at $0-48 \mathrm{~h}$ following stimulation with $1 \mathrm{~mm}$ dibutyryl cAMP. GTP-bound Rac1 or Cdc42 was affinity precipitated with GST-CRIB, which specifically binds to GTP-bound Rac1 and Cdc42, from Schwann cell lysates, and immunoblotted with an anti-Rac1 or Cdc42 antibody. Total Rac1 and Cdc42 levels were comparable. GTP-bound Rac1 and Cdc42 are shown as relative values $(n=3)$. $\boldsymbol{E}, \boldsymbol{F}$, JNK1 in Schwann cell lysates was immunoprecipitated with anti-JNK1 antibody from Schwann cell lysates and immunoblotted with an anti-(pThr183/pTyr185)JNK antibody, which recognizes active JNK. Total JNK1 levels were comparable. JNK phosphorylation is shown as a relative value $(n=3) . \mathbf{G}, \boldsymbol{H}$, Schwann cells were treated with or without $1 \mathrm{~mm}$ dibutyryl cAMP in the presence or absence of $10 \mu \mathrm{m}$ JNK inhibitor I or SP600125 for $48 \mathrm{~h}$. The percentages of MBP-expressing Schwann cells are shown $(n=4)$. Data were evaluated using one-way ANOVA ( ${ }^{*} p<0.01$; $^{* *} p<0.02$ ).

in $50 \%$ formamide $/ 2 \times \mathrm{SSC}$ at $37^{\circ} \mathrm{C}$ and then in $1 \times \mathrm{SSC}$ at room temperature for $20 \mathrm{~min}$ each, and then counterstained with DAPI. FISH images were captured using a DMRA2 microscope system (Leica) and CW4000 FISH software (Leica).

In vitro myelination and transfection. Dissociated explants were established from mice on Embryonic Day 13 (Chan et al., 2006). DRGs were collected and dissociated using $0.25 \%$ trypsin and trituration. Cells were electrofected with the plasmid encoding GFP-tagged Dock7 shRNAresistant Dock7, using the Nucleofector II device (Lonza), according to the manufacturer's instruction (program O-08). The shRNA-resistant Dock7 was the construct that replaced 5'-AAGACGTTCAATGTCAAT

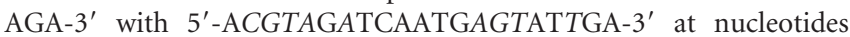
207-227 without amino acid mutations (italicized nucleotides indicate their replacements) (Yamauchi et al., 2008). Cells were dispersed and plated onto collagen-coated coverslips ( 300,000 cells/coverslip). The dissociated explants were maintained in MEM containing 10\% FBS and 100 $\mathrm{ng} / \mathrm{ml}$ NGF. Axonal processes and endogenous Schwann cells were allowed to grow and establish themselves for $5 \mathrm{~d}$. For induction of myelination, $50 \mu \mathrm{g} / \mathrm{ml}$ ascorbic acid was added. Culture medium was changed every 2-3 d and cultures were maintained for an additional $10 \mathrm{~d}$. Myelination was assessed by immunostaining with an anti-MBP antibody.

Immunohistochemistry. Tissues were perfused first with PBS and then with $4 \%$ paraformaldehyde and were subsequently postfixed with $4 \%$ paraformaldehyde. They were then replaced in $20 \%$ sucrose and embedded in Tissue-Tek reagent (Sakura Finetechnical). Ten micrometers of microtome sections were blocked and incubated first with primary antibodies and then with fluorescence-labeled secondary antibodies. The glass coverslips were mounted with Vectashield reagent. The fluorescent images were captured using a DM2500 fluorescence microscope system (Leica).

Electron microscopy. Sciatic nerves were fixed with $2 \%$ glutaraldehyde and $2 \%$ paraformaldehyde in $0.1 \%$ cacodylate buffer, contrasted with $2 \%$ osmium tetroxide, dehydrated with an ethanol gradient, and treated with propylene oxide. Finally, samples were infiltrated and embedded in pure epoxy. Thin sections were cut and stained with uranyl acetate and lead staining solution. Images were taken with a JEM-1200EX electron microscope system (JEOL).

Statistical analysis. Values shown represent the mean \pm SD from separate experiments. A one-way ANOVA was followed by a Fisher's protected least significant difference test as a post hoc comparison $\left({ }^{*} p<0.01 ;{ }^{* *} p<0.02\right)$.

\section{Results}

Dock7 knockdown promotes a cell-permeable cAMP analog-induced Schwann cell morphological differentiation

We previously reported that the signaling pathway coupling Dock180-related protein, Dock7, and the target Rho GTPases $\mathrm{Rac} / \mathrm{Cdc} 42$ to the JNK cascade positively regulates Schwann cell migration before the initiation of myelination (Yamauchi et al., 2008). In the present study, we explored whether Dock7 is involved in Schwann cell differentiation and myelination and, if so, whether signaling through Dock7 in migration is preserved, at least in part, in the myelination process.

We first determined the expression pattern of the Dock7 protein by immunoblotting with an affinity purified antibody specific to Dock7 (Fig. $1 D$ ) in sciatic nerve development. As shown in Figure 1, $A$ and $B$, sciatic nerves displayed moderate to high expression levels of Dock7 from the embryonic stage to Postnatal Day 6. Thereafter, as development proceeded, Dock7 was gradually downregulated. In contrast, the expression levels of Rac1/Cdc42 and actin as the control remained stable during this period. Similar results were observed regarding the phosphorylation of Dock7 at the Tyr1118 position, which is critical for upregulation of the catalytic GEF activity of Dock7 (Yamauchi et al., 2008), indicating that the expression and activation of Dock7 are regulated in parallel in sciatic nerves. RT-PCR analysis showed that Dock7 mRNA was abundantly present in primary Schwann cells (Fig. $1 C$ ). The transcription of actin or Dock11 as the control was comparable. Although sciatic nerve tissue contains fibroblasts as well as Schwann cells and peripheral axonal fibers, the presence of Dock7 in sciatic nerves after birth suggests the potential role of Dock7 in the onset of myelination.

Treatment with a cell-permeable cAMP analog such as dibutyryl cAMP in primary Schwann cells mimics axonal contact in vitro and induces their morphological differentiation from a spindle cell shape to a more flattened shape extending branched 
processes, accompanied by the expression of myelin marker proteins such as MBP and MPZ (Sobue et al., 1986; D'Antonio et al., 2006; Monje et al., 2010). Differentiated Schwann cells often form a myelin web-like structure with fenestrated cytoplasmic sheets (Sobue et al., 1986; D’Antonio et al., 2006; Monje et al., 2010; see Fig. $2 B$, bottom panels). We used this established in vitro Schwann cell differentiation system and investigated the role of Dock7 in morphological differentiation. Treatment with dibutyryl cAMP promoted the extension of MBP-positive processes, whose morphological changes depended on the concentration of dibutyryl cAMP (Fig. $2 B, C$ ). In the case of treatment with $1 \mathrm{~mm}$ dibutyryl cAMP, control luciferase (si)RNA-transfected Schwann cells exhibited phenotypes with MBP-positive processes by $\sim 10 \%$ (Fig. $2 B, C)$. In contrast, transfection with Dock7 siRNA into Schwann cells promoted dibutyryl cAMP-induced morphological changes in $\sim 20 \%$ of cells (Fig. $2 B, C)$. The expression of Dock7 was markedly reduced by transfection with Dock7 siRNA, whereas the expression of control proteins was unaffected, as revealed by immunoblotting analysis (Fig. $2 A)$. We next examined the effect of Dock7 knockdown on the expression of MPZ, another myelin marker, in Schwann cells. Dock7 siRNA transfection resulted in twofold to threefold upregulation of MPZ expression compared with transfection with control siRNA (1 mM dibutyryl cAMP; Fig. $2 D, E)$. Together, these results provide evidence that Dock7 negatively regulates Schwann cell morphological differentiation.

\section{Dock7 knockdown leads to shorter duration of Rac/Cdc42/ JNK activation and earlier activation of Rho/Rho-kinase in Schwann cells}

The Rac, Cdc42, and Rho proteins are key regulators that control many aspects of cell morphological changes and differentiation (Hall, 1998; Kaibuchi et al., 1999; Bar-Sagi and Hall, 2000; Takai et al., 2001). Racl is highly involved in the formation of the myelin sheath in sciatic nerves in vivo (Benninger et al., 2007; Chan, 2007; Nodari et al., 2007). Dock7 directly activates Rac1 and Cdc42, resulting in the downstream activation of the JNK mitogen-activated protein kinase cascade to promote Schwann cell migration (Yamauchi et al., 2008). Therefore, we examined whether Rac1, Cdc42, and JNK, acting through Dock7, are activated in differentiating Schwann cells.

The activity levels of Racl and Cdc42 were measured through affinity precipitation with the isolated CRIB of Pak1, which specifically binds to activated GTP-bound Rac1 and Cdc42. The affinity precipitation assay revealed that $\mathrm{Racl}$ and $\mathrm{Cdc} 42$ were activated at least during the periods from 12 to $36 \mathrm{~h}$ (Fig. $3 \mathrm{~A}, B$ ) and 12 to $24 \mathrm{~h}$ (Fig. $3 C, D$ ), respectively, after stimulation with dibutyryl cAMP. In the case of Dock7 knockdown, on the other hand, Rac1 and Cdc42 activation was abolished $12 \mathrm{~h}$ after stimulation with dibutyryl cAMP (Fig. $3 A-D$ ), indicating that Dock7 is involved in the activation of Racl and Cdc42 in the early stage of Schwann cell morphological differentiation.

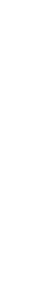
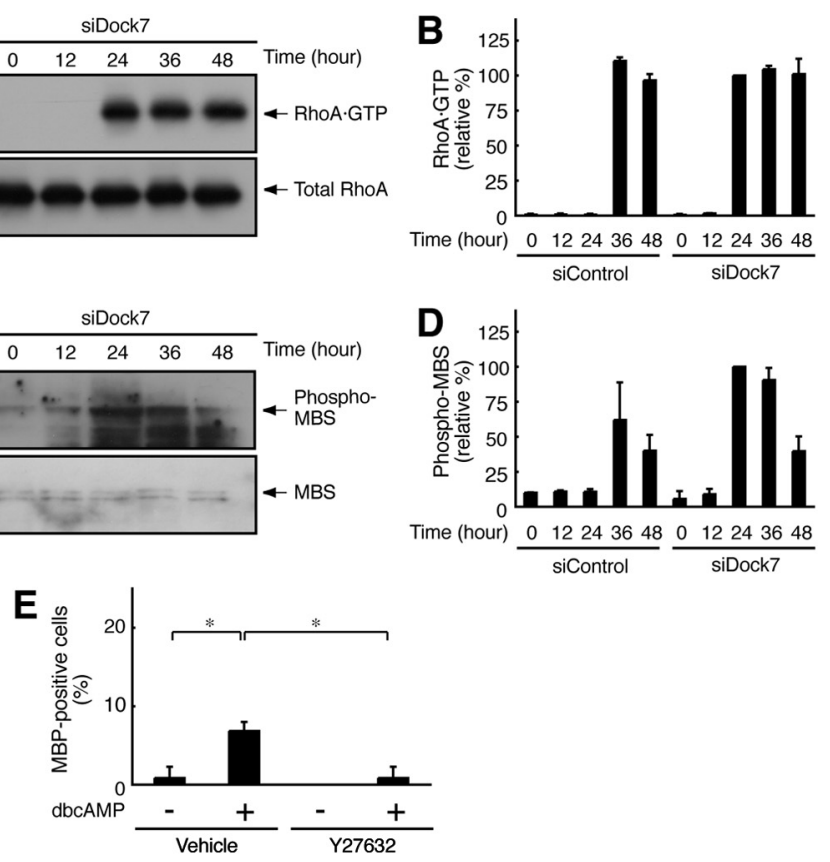

siControl $\frac{0-122436}{\text { siDock7 }}$
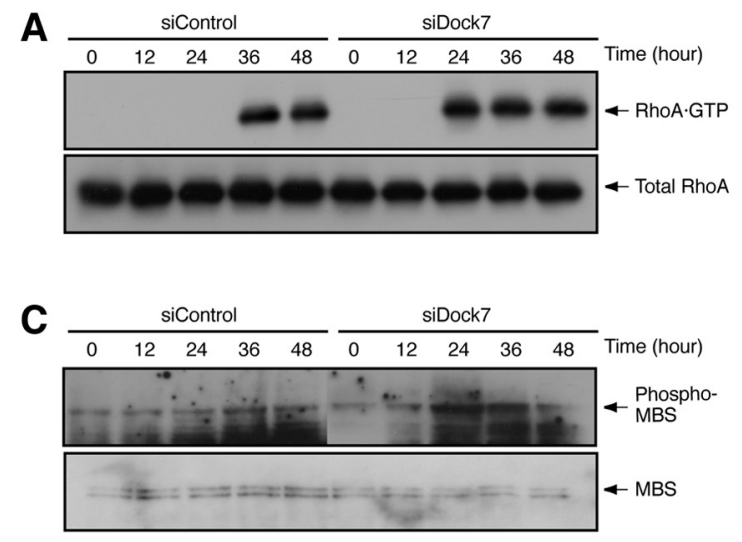

Figure 4. Dock7 knockdown changes RhoA/Rho-kinase signaling in Schwann cells. $\boldsymbol{A}, \boldsymbol{B}, \mathrm{GTP}$-bound RhoA was affinity precipwith GST-RBD, which specifically binds to GTP-bound RhoA, from Schwann cell lysates, and immunoblotted with an antior without $1 \mathrm{~mm}$ dibutyryl cAMP in the presence or absence of $10 \mu \mathrm{M}$ Y 27632 for $48 \mathrm{~h}$. The percentages of MBP-expressing Schwann cells are shown $(n=4)$. Data were evaluated using one-way ANOVA $\left({ }^{*} p<0.01\right)$.

We next investigated whether dibutyryl cAMP activates JNK through Dock7 in Schwann cells. JNK activity was detected by immunoblotting with an anti-(pThr183/pTyr185)JNK antibody, which recognizes the active state. Dibutyryl cAMP resulted in JNK activation from 12 to $24 \mathrm{~h}$, whereas Dock7 knockdown abolished this activation $12 \mathrm{~h}$ after stimulation (Fig. $3 E, F$ ). This observation is consistent with the finding that Dock7 supports the activation of Racl and Cdc42 in an early stage, although JNK activity was severely weakened by Dock7 knockdown (Fig. 3 E, F). Indeed, JNK activation is dependent on Dock7 in Schwann cells, although it is conceivable that Racl and Cdc42 have multiple targets other than JNK (Hall, 1998; Kaibuchi et al., 1999; Bar-Sagi and Hall, 2000; Takai et al., 2001).

We confirmed that JNK inhibition participates in the promotion of Schwann cell differentiation because Dock7 knockdown promotes morphological differentiation. Treatment of Schwann cells with structurally different JNK inhibitors, such as JNK inhibitor I or SP600125, promoted dibutyryl cAMP-induced morphological differentiation (Fig. $3 G, H$ ), which is consistent with the finding that JNK signaling is negatively involved in Schwann cell differentiation and myelination (Kaempchen et al., 2003; Parkinson et al., 2004; Monje et al., 2010).

The Rac and Cdc42 signals often antagonize the Rho signals, which regulate many aspects of cell morphological changes (Hall, 1998; Kaibuchi et al., 1999; Bar-Sagi and Hall, 2000; Takai et al., 2001). Knowing this, we undertook to measure the RhoA activity in Schwann cells. RhoA activity was measured through affinity precipitation with the isolated RBD of $\mathrm{mDia}$, which specifically binds to activated GTP-bound RhoA. RhoA was activated $36 \mathrm{~h}$ after stimulation with dibutyryl cAMP (Fig. 4A, B). RhoA activation apparently follows the activation of Racl and Cdc42 (Fig. $3 A-D)$. In contrast, Dock7 knockdown caused RhoA activation 
A
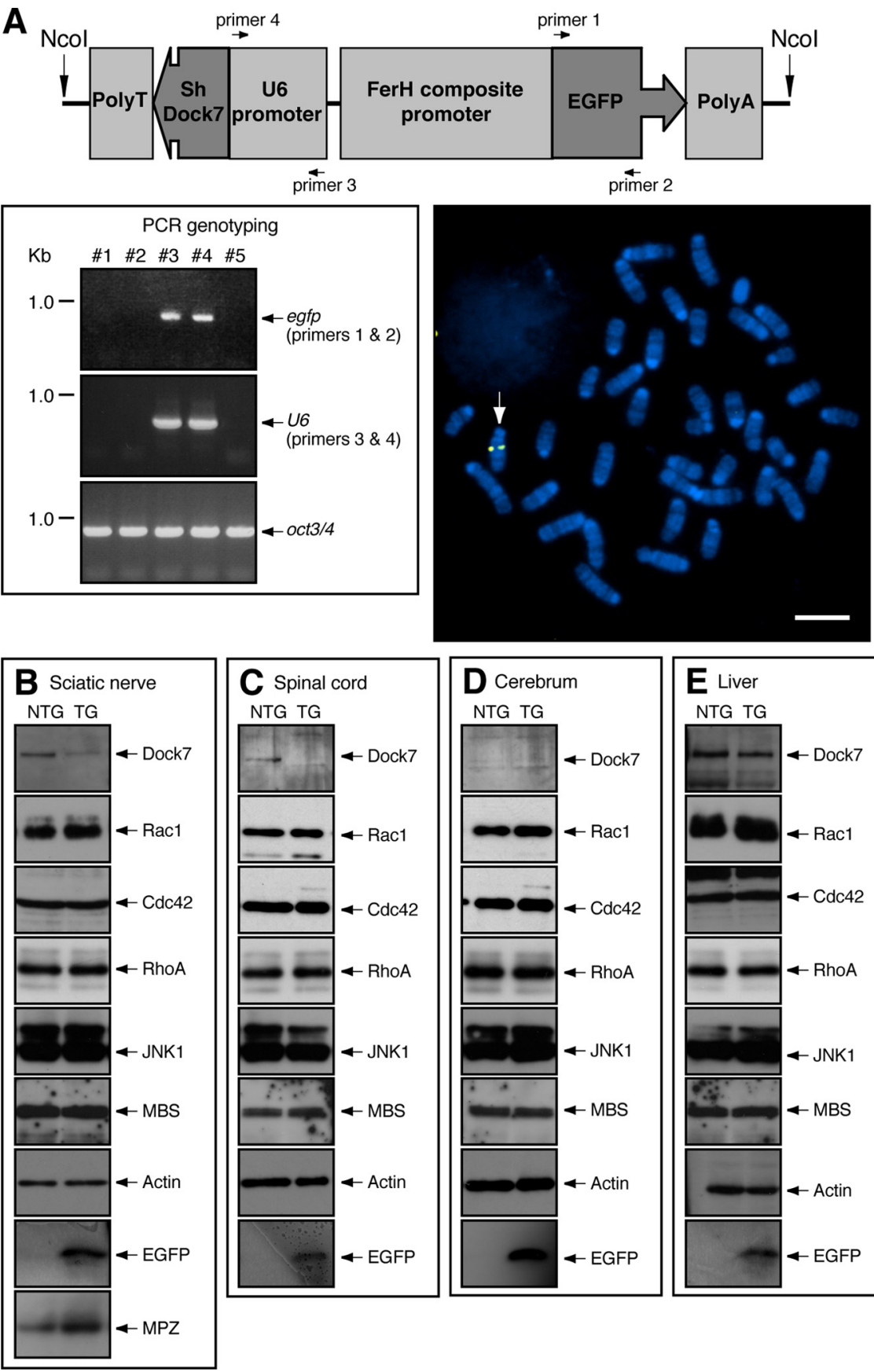

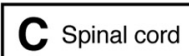
NTG TG
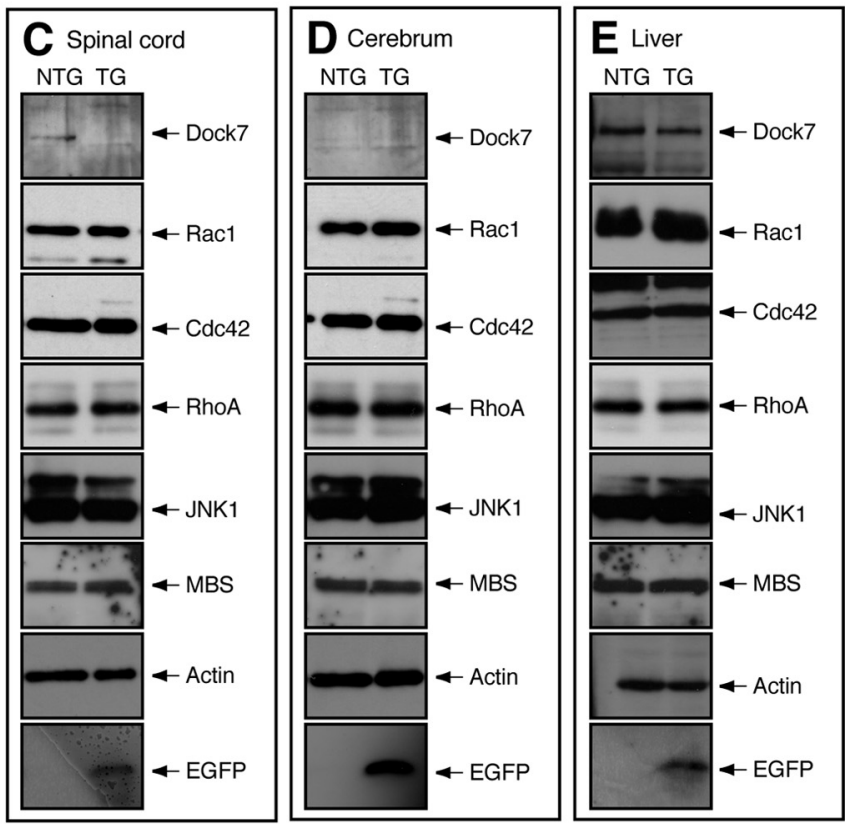

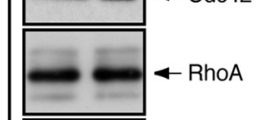

Figure 5. Expression of Dock7 shRNA in mice. A, Schematic diagram of the injected, linearized DNA possessing both the Dock7 shRNA transcription sequence (U6 promoter, Dock7 shRNA, and RNA transcription stop signal) and the EGFP translation sequence (ferritin heavy chain FerH composite promoter, EGFP, and EF1 polyA) (top panel). Mouse genotyping was performed by PCR with the specific primer pairs for the egfp (primers 1 and 2) and mouse U6 (primers 3 ad 4) sequence. The oct $3 / 4$ gene is also shown as a control. In this experiment, Mouse \#3 and Mouse \#4 are transgene-positive (bottom left panel). Dock7 shRNA transgenic mouse splenocytes were isolated and splenocyte chromosomes were used in FISH analysis with a $\mathrm{Cy} 3$ (red)-labeled probe. They were also costained with DAPI (blue). The arrow indicates the FISH-positive position of Chromosome 12 (bottom right panel). Scale bar, 10 $\mu \mathrm{m} . \boldsymbol{B}-\boldsymbol{E}$, Expression of Dock7, Rho GTPase, JNK1, MBS, EGFP, and actin in the tissues of 7-d-old Dock7 shRNA transgenic mice (TG) or nontransgenic littermates (NTG) tissues was confirmed using immunoblotting with each specific antibody. $\boldsymbol{B}$, Extracts from the sciatic nerve tissues were immunoblotted with an anti-MPZ antibody.

to begin $24 \mathrm{~h}$ after stimulation (Fig. $4 A, B$ ), suggesting that RhoA may participate in the promotion of Schwann cell morphological differentiation.

Next, we tested whether dibutyryl cAMP activates Rhoassociated kinase, the major effector of RhoA, in Schwann cells. Rho-kinase activity was detected by immunoblotting with an
anti-(pThr853)MBS antibody, which recognizes the Rho-kinase phosphorylation of MBS. Treatment with dibutyryl cAMP resulted in MBS phosphorylation $36 \mathrm{~h}$ after stimulation. In contrast, Dock7 knockdown caused MBS phosphorylation to begin $24 \mathrm{~h}$ after stimulation (Fig. $4 C, D)$, as seen in the activation profile of RhoA. Importantly, Rho-kinase is a positive regulator of myelination by Schwann cells in vitro (Melendez-Vasquez et al., 2004). It is possible that Dock7 knockdown leads to indirect upregulation of Rho-kinase and promotes Schwann cell morphological differentiation. This idea is supported by the finding that treatment of Schwann cells with Y27632, the specific inhibitor of Rho-kinase, blocked dibutyryl cAMP-induced morphological differentiation (Fig. $4 E$ ).

Dock7 shRNA transgenic mice display enhanced myelin thickness in sciatic nerves

We tested whether Dock7 negatively regulates myelination in sciatic nerves of the peripheral nervous system. To knockdown Dock7 in vivo, we generated Dock7 shRNA transgenic mice (Fig. $5 \mathrm{~A}$ ) according to the conventional method (Peng et al., 2006): briefly, we injected a DNA fragment containing a Dock7 shRNA transcription sequence controlled under a U6 promoter and a nucleotide sequence to express EGFP as a marker into fertilized mouse oocytes. The transgenic mice appeared healthy and normally bred. When compared with control nontransgenic littermates, the transgenic mice exhibited decreased levels of Dock7 protein and increased expression of MPZ (260 $\pm 28 \%$, $n=3$ ). The protein levels were detected by immunoblotting with each specific antibody (Fig. $5 B$ ). Other control proteins, namely, Rho GTPases, JNK1, MBS, and actin, behaved comparably.

In comparison, we checked the effects of Dock7 knockdown on two other nervous tissues (spinal cord and cerebrum) and the liver. Dock7 was knocked down in the spinal cord (Fig. 5C) and liver (Fig. $5 E$ ), despite a very low detectable level of Dock7 in cerebrum (Fig. 5D). The efficiency of knockdown likely varies depending on tissues and organs (Peng et al., 2006).

We next tested whether primary Schwann cells from Dock7 shRNA transgenic mice have the ability to promote Schwann cell differentiation for myelin sheath formation. We used the established in vitro Schwann cell/DRG neuronal culture system (Chan et al., 2006). Embryonic DRGs were dissociated with trypsin and cultured for Schwann cell proliferation in association with axons. Schwann cells were treated with ascorbic acid to initiate myelination and 


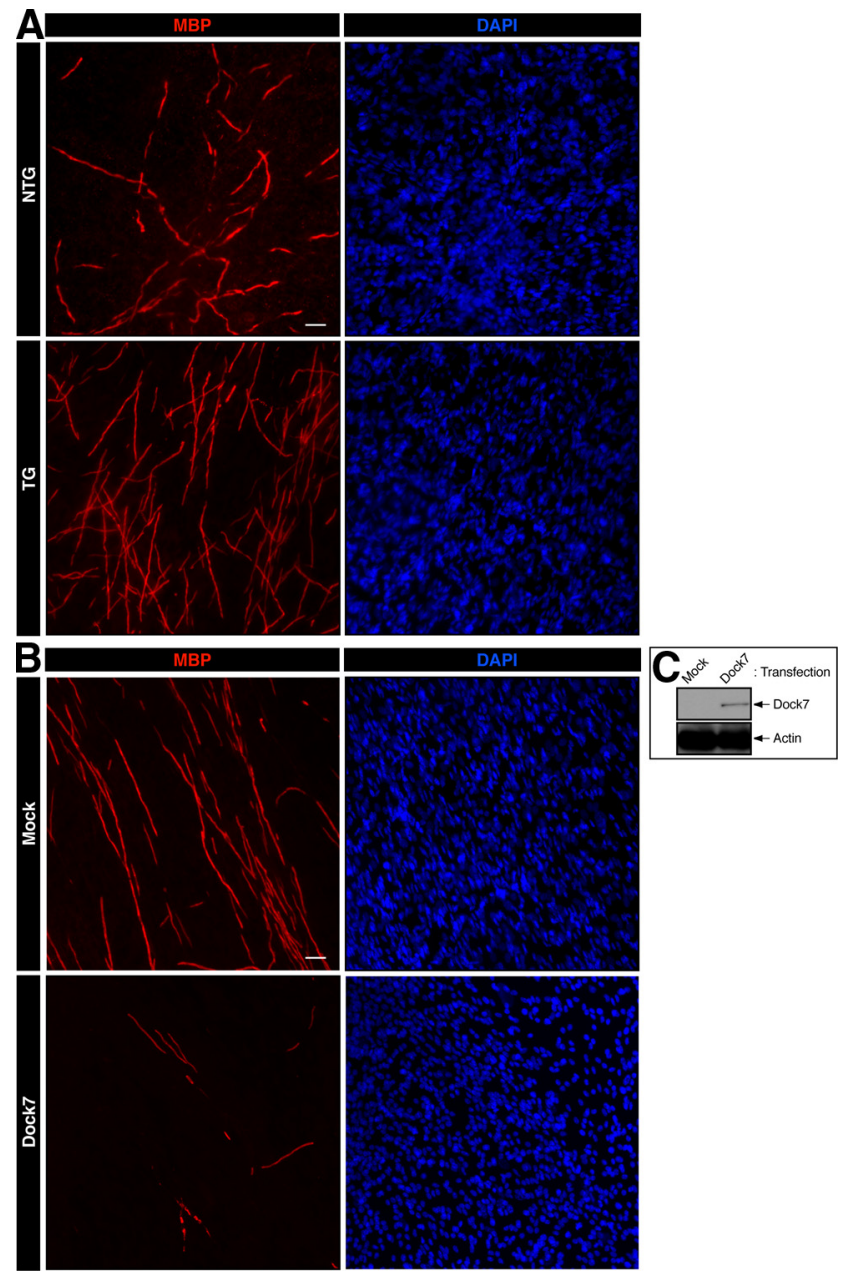

Figure 6. Dock7 shRNA transgene promotes myelination by Schwann cells. $\boldsymbol{A}$, Representative images of in vitro myelination from cultures established from a Dock7 shRNA transgenic mouse (TG) and a nontransgenic littermate (NTG). Cultures were costained with an anti-MBP antibody (red) and DAPI (blue) to observe myelination and total cell numbers, respectively. $\boldsymbol{B}$, Representative images of in vitro myelination from cultures established from a Dock7 shRNA transgenic mouse with or without transfecting the plasmid encoding GFP-tagged shRNA-resistant Dock7. C, Expression of transfected Dock7 and the control actin is shown. Scale bar, $30 \mu \mathrm{m}$.

were allowed to wrap individual axons. Cultures were stained with an anti-MBP antibody to enable the visualization of myelin segments. Representative images of the cultures are presented in Figure 6 A. Dock7 knockdown promoted myelination (the number of myelin segments) in culture (in $225 \mu \mathrm{m}$ square fields, $150 \pm 34, n=5$ of transgenic mice; compared with $65 \pm 5.7, n=$ 5 of nontransgenic littermates). In addition, we transfected the plasmid encoding shRNA-resistant wild-type Dock7 into Dock7 shRNA transgenic Schwann cells (Fig. 6B,C). We expected that Dock7 expression would either permit normal myelination or inhibit myelination; as it turned out, it inhibited myelination (in $225 \mu \mathrm{m}$ square fields, $13 \pm 5.4, n=4$ of Dock7-transfection; compared with $120 \pm 33, n=4$ of mock transfection), supporting the idea that Dock7 knockdown negatively regulates myelination. The findings that Dock7 knockdown upregulates the myelin marker protein in transgenic mouse sciatic nerves and increases myelination in the culture system are in agreement with the results of our in vitro knockdown experiments. However, Dock7 knockdown in mice did not have a significant effect on Schwann cell lineage cell number in embryonic peripheral ganglia or in 7-d-old sciatic nerves (Fig. 7A,B) or on Schwann cell proliferation in culture (Fig. 7C). In contrast, it did have an inhibitory effect on Schwann cell migration in assays using Boyden chambers (Fig. 7D) and Schwann cell reaggregates (Fig. 7E,F), consistent with our previous results from Dock7 siRNAtransfected primary Schwann cells (Yamauchi et al., 2008). Dock7 knockdown in Schwann cells in vitro (Fig. 7D-F) decreased their ability to migrate, but the in vivo knockdown did not seem to alter this ability (Fig. $7 A-C$ ). The reason for this may be that migration in vivo is robustly assisted by growth factors and/or extracellular matrixes, which are not present in sufficient quantities or perhaps at all in vitro. Alternatively, other cells such as peripheral nerve fibroblasts may help Schwann cells to properly migrate in vivo.

Because knockdown of Dock7 occurred everywhere in tissues, we examined the effect of Dock7 knockdown on the morphologies of primary DRG neurons (Fig. 8). There were apparently no significant differences caused by Dock7 knockdown: neurons of Dock7 shRNA transgenic mice and those of nontransgenic littermates had comparable axon lengths $(230 \mu \mathrm{m} \pm 41 \mu \mathrm{m}, n=40$ of transgenic mice; compared with $230 \mu \mathrm{m} \pm 33 \mu \mathrm{m}, n=40$ of nontransgenic littermates), axon numbers $(2.0 \pm 1.0, n=$ 40 of transgenic mice; compared with $2.0 \pm 0.71, n=40$ of nontransgenic littermates), and branching ( $2.5 \pm 1.1, n=40$ of transgenic mice; compared with $2.5 \pm 0.87, n=40$ of nontransgenic littermates).

Consistent with the increased myelination seen in Dock7 shRNA transgenic Schwann cells, the transgenic mice exhibited enhanced myelin thickness in electron micrographs of the sciatic nerve cross-section on Postnatal Day 7 (Fig. 9A, the transgenic mouse in comparison with the nontransgenic littermate). To obtain the statistical data, we calculated $g$-ratios, which are the numerical ratios between the diameter of the axon proper and the outer diameter of the myelinated fiber. The average $g$-ratio in nontransgenic littermates was $0.73 \pm 0.070(n=114$ in two independent mice) (Fig. $9 \mathrm{~B}, \mathrm{C}$ ). This value is in agreement with those in previous reports (Michailov et al., 2004; Tao et al., 2009). In contrast, the average $g$-ratio in transgenic mice was $0.59 \pm$ $0.086(n=90$ in two independent mice) (Fig. $9 B, C)$, indicating the negative role of Dock7 in the onset of myelination. Comparable were the average axon numbers of nontransgenic littermates and transgenic mice ( $75 \pm 15$ per $50 \mu \mathrm{m}$ square field, $n=4$; and $77 \pm 18$ per $50 \mu \mathrm{m}$ field, $n=4$ ), in which entirely wrapped axons were $67 \pm 8.8 \%$ and $65 \pm 9.9 \%$, respectively. There was a tendency toward decreased axon diameters in 7-d-old transgenic mice ( $1.8 \mu \mathrm{m} \pm 0.53 \mu \mathrm{m}, n=90$; compared with $2.0 \mu \mathrm{m} \pm 0.54$ $\mu \mathrm{m}, n=114$ of nontransgenic littermates). On further examination of the sciatic nerve cross-section by electron microscopy, myelinated axons were observed at every developmental stage that we tested (Fig. 10). The observable defects in axonal sorting were not detected in sciatic nerve cross-sections at an earlier stage (3 d old). In addition, transgenic mice still exhibited slightly enhanced myelin thickness in electron microscopic analysis of sciatic nerve cross-sections even at 1 month, although the difference was smaller than that at earlier stages. The average $g$-ratio ( 1 month) in nontransgenic littermates was $0.63 \pm 0.058(n=70$ in two independent mice) and that in transgenic mice was $0.60 \pm$ 0.052 ( $n=73$ in two independent mice).

This effect of Dock7 knockdown typically overcomes later in development, suggesting that the most important role of Dock7 is its effect on the onset of myelination. A similar effect was observed in average axon diameter, which also recovered during development; by 1 month of age, the average axon diameter in transgenic mice $(2.6 \mu \mathrm{m} \pm 0.76 \mu \mathrm{m}, n=73)$ became equivalent 
A
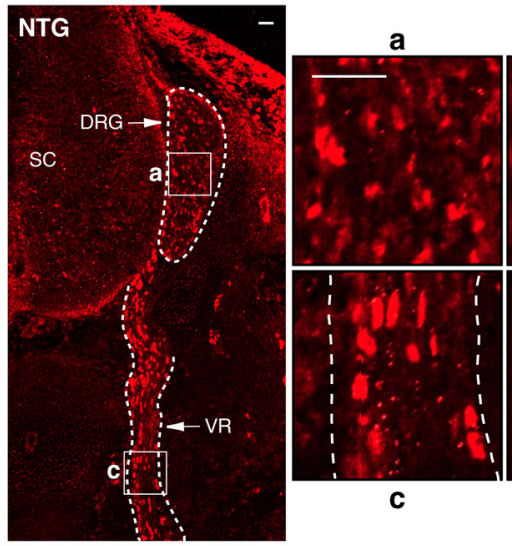

C
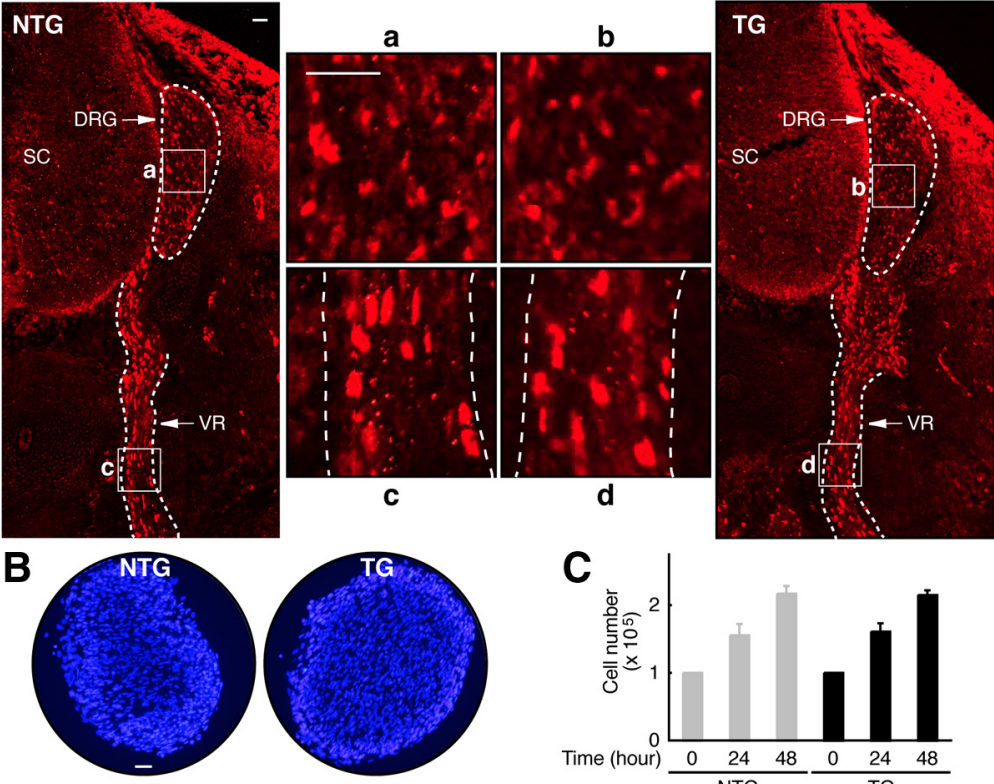

C
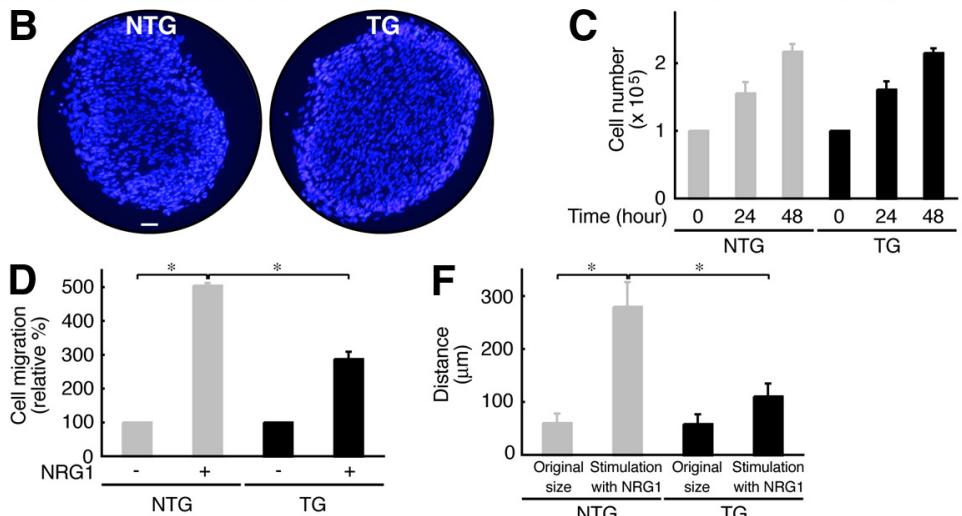

E

Original size
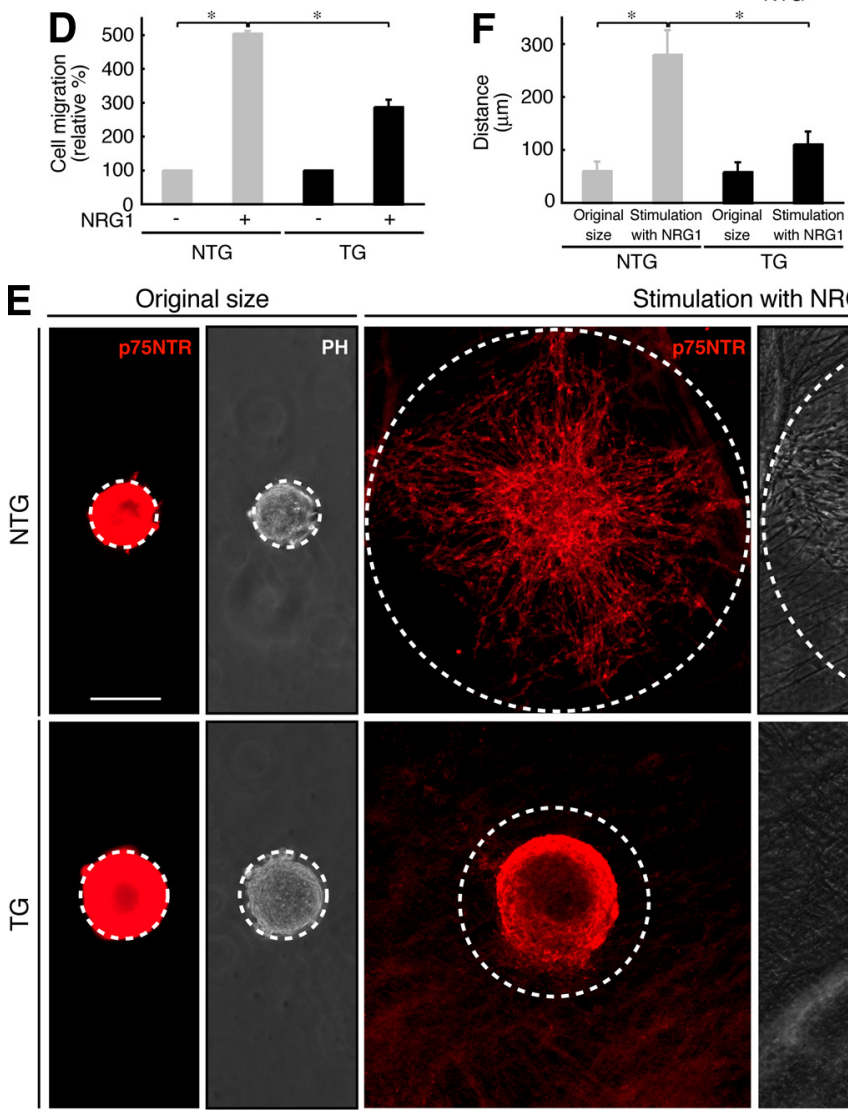

Stimulation with NRG1
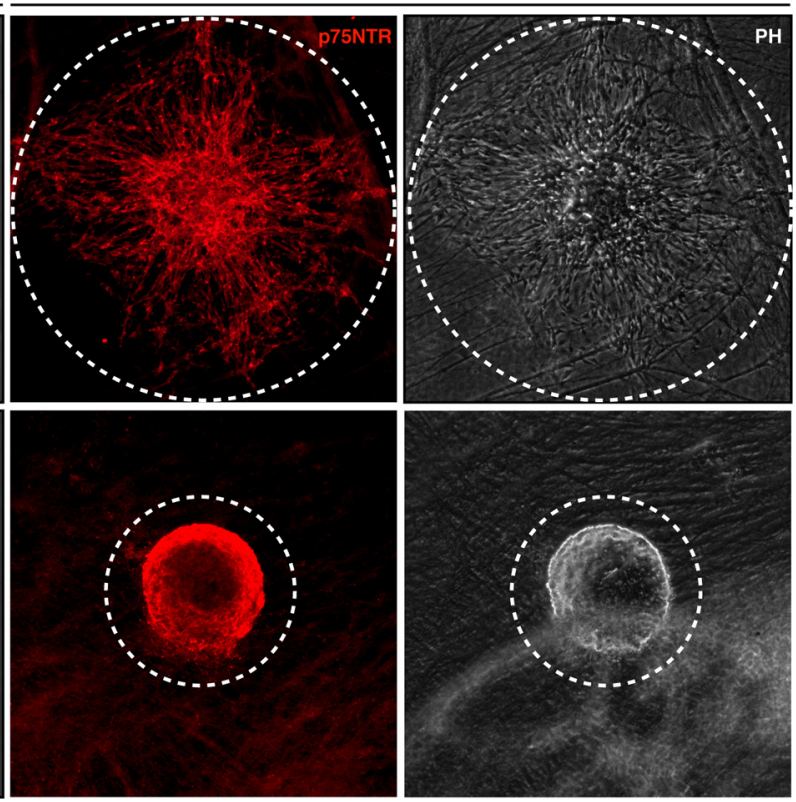

Figure 7. Cell number and migratory activity of Dock7 shRNA transgenic mouse Schwann cells. $\boldsymbol{A}$, Embryonic Day 14.5 cross-sections along the spinal cord region (SC) and the ventral root (VR) from Dock7 shRNA transgenic mice (TG) and nontransgenic littermates (NTG) were stained with an anti-Sox10 antibody (red) to observe the total cell number of the Schwann cell lineage in the peripheral ganglia. The small letters $\boldsymbol{a}$ - $\boldsymbol{d}$ are magnifications of the boxed areas (left and right large sections). The outlines of the DRG and VR are surrounded by dotted lines. Scale bars, $50 \mu \mathrm{m}$. B, Cross-sections of 7-d-old sciatic nerves in transgenic and nontransgenic mice were stained with DAP (blue) to observe the total cell number. Scale bar, $100 \mu \mathrm{m}$. C, Schwann cells from transgenic and nontransgenic mice were treated with 10 $\mathrm{ng} / \mathrm{ml}$ neuregulin- 1 and $5 \mu \mathrm{m}$ forskolin for $0-48 \mathrm{~h}$ and counted using a hemocytometer $(n=3)$. D, Schwann cell migration was assayed in the presence or absence of $10 \mathrm{ng} / \mathrm{ml}$ neuregulin- 1 for $6 \mathrm{~h}$ using Boyden chambers. Migrating Schwann cells were fixed, stained with Giemsa solution, and counted $(n=3) . \boldsymbol{E}, \boldsymbol{F}$, Schwann cell reaggregates were placed onto live DRG axons and allowed to migrate for $6 \mathrm{~h}$. Schwann cells were stained with an anti-p75NTR antibody (red) and the distance of migration from the center of the reaggregate was measured (indicated by dotted lines) $(n=3)$. Phase-contrast (PH) images are also shown. The dotted lines indicate the original size of the reaggregates or the outer line of migrating cells. Scale bar, $100 \mu \mathrm{m}$. Data were evaluated using one-way ANOVA ( $\left.{ }^{*} p<0.01\right)$. to that of nontransgenic littermates (2.7 $\mu \mathrm{m} \pm 0.70 \mu \mathrm{m}, n=70$ ). Although Dock7 was detectable in DRG neurons by RTPCR analysis (Fig. 1C), Dock7 levels were much lower in DRG neurons than in Schwann cells. Because myelinating glial cells have some effect on axon development (de Waegh et al., 1992; Sánchez et al., 1996), it is possible that Dock7 in Schwann cells may be involved in the proper adjustment of the axon diameter.

The mechanism behind Dock7 knockdown was analyzed by immunoblotting with antibodies specific for the proteins that are thus far known to control myelination in sciatic nerves. The transcription factors Oct6 (also called Scip) and Krox20 (also called Egr2) were examined (Fig. $11 A, B$ ) (Mirsky and Jessen, 1996; Nave and Salzer, 2006). In the sciatic nerves of Dock7 shRNA transgenic mice on Postnatal Day 1 , a very slightly decreased expression of Oct6 and a very slightly increased expression of Krox20 were observed, suggesting that Dock7 knockdown positively controls the onset of myelination. Neuregulin- 1 is the ErbB2/3 ligand that integrates myelination and also activates Dock7 in Schwann cells (Michailov et al., 2004; Nave and Salzer, 2006), but the expression of neuregulin-1 was comparable in transgenic mice and nontransgenic littermates (Fig. 11C), suggesting that Dock7 knockdown may affect an intracellular signaling most strongly. Akt is a cytoplasmic kinase and is known to promote myelination (Ogata et al., 2004; Nave and Salzer, 2006). Phosphorylation of Akt at the Ser-473 position is critical for its activation. Dock7 knockdown increased Akt phosphorylation at the Ser473 position without a detectable change in Akt expression (Fig. 11D). In addition, the only known protein downstream of Dock7 in neurons is stathmin (also known as Op18), which is one of the regulators of tubulin dynamics (WatabeUchida et al., 2006). Phosphorylation of stathmin at the Ser-16 position is mediated by Dock7 (Watabe-Uchida et al., 2006) and Rac1/Cdc42 (Daub et al., 2001) and controls axon morphogenesis in hippocampal neurons. Dock7 knockdown resulted in a decrease of stathmin phosphorylation without a detectable change of stathmin expression (Fig. 11E), implying that Dock7 may have an effect on axon morphogenesis, perhaps in the adjustment of the axon diameter in developing sciatic nerves. The expression of actin was comparable (Fig. 11F). Although knockdown of Dock7 in vivo affects the regulation of axon diameter and myelination by 

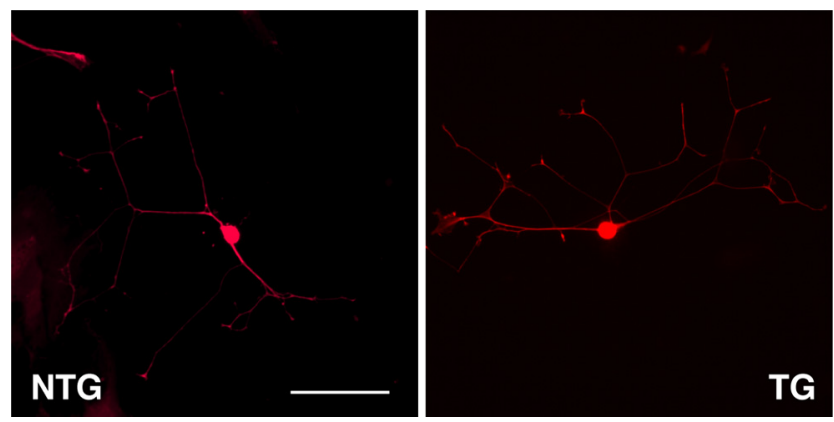

Figure 8. Cell morphology of Dock7 shRNA transgenic mouse DRG neurons. DRG neurons from a Dock7 shRNA transgenic mouse (TG) and a nontransgenic littermate (NTG) were cultured for $2 \mathrm{~d}$ and stained with an anti-neurofilament antibody (red). Scale bar, $100 \mu \mathrm{m}$.

Schwann cells, the results presented here are consistent with the observation that Dock7 knockdown promotes Schwann cell morphological differentiation and myelination in culture and suggest that Dock7 should be added to the list of regulators that control myelination by Schwann cells.

Dock7 knockdown increases RhoA/Rho-kinase activity and decreases Rac1/Cdc42/JNK activity in sciatic nerves

Compared with the nontransgenic littermates, Dock7 shRNA transgenic mice exhibited decreased Racl and Cdc42 activity ( $59 \pm 9.0 \%, n=4$, and $44 \pm 6.8 \%, n=4)$ and decreased JNK phosphorylation $(42 \pm 8.6 \%, n=4)$ in sciatic nerves (Fig. 12A$C)$. In the transgenic mice, on the other hand, increased RhoA and Rho-kinase activity $(370 \pm 28 \%, n=4$, and $150 \pm 10 \%, n=$ 4) were observed (Fig. $12 D, E$ ). The effects of the in vivo knockdown on signaling molecules are similar to those of the in vitro knockdown.

\section{Discussion}

In the middle embryonic to postnatal developmental stages, Schwann cells in the peripheral nervous system are unique in accomplishing continuous, dynamic morphological changes such as migration and differentiation to form the myelin sheath. The molecular mechanisms underlying each step in this process are still unclear. Herein, we demonstrate the unexpected role of Dock7 in Schwann cell differentiation and myelination; it negatively regulates differentiation and myelination in vivo, as shown in the present study, although it enhances Schwann cell migration in vitro, as shown previously (Yamauchi et al., 2008). This conclusion is supported by the observation that knockdown of Dock7 by siRNA in primary Schwann cells in vitro promotes dibutyryl cAMP-induced morphological differentiation. Dock7 knockdown also results in a shorter duration of Rac1/Cdc42/JNK activation and an earlier activation of RhoA/Rho-kinase. Dock7 shRNA transgenic mice exhibit increased Schwann cell myelination in vitro and increased sciatic nerve myelin thickness at early developmental stages in vivo, accompanied by decreased activities of Rac1/Cdc42/JNK and increased activities of RhoA/Rhokinase. It is known that JNK signaling pathway negatively regulates Schwann cell differentiation and myelination (Kaempchen et al., 2003; Parkinson et al., 2004; Monje et al., 2010) and that Rho-kinase positively regulates myelination (MelendezVasquez et al., 2004). To the best of our knowledge, this is the first report of a Rho GTPase-GEF negatively regulating Schwann cell differentiation and myelination. Our conclusions may be supported by the observation that Dock7 in sciatic nerves is developmentally downregulated; it expresses strongly in earlier stages but
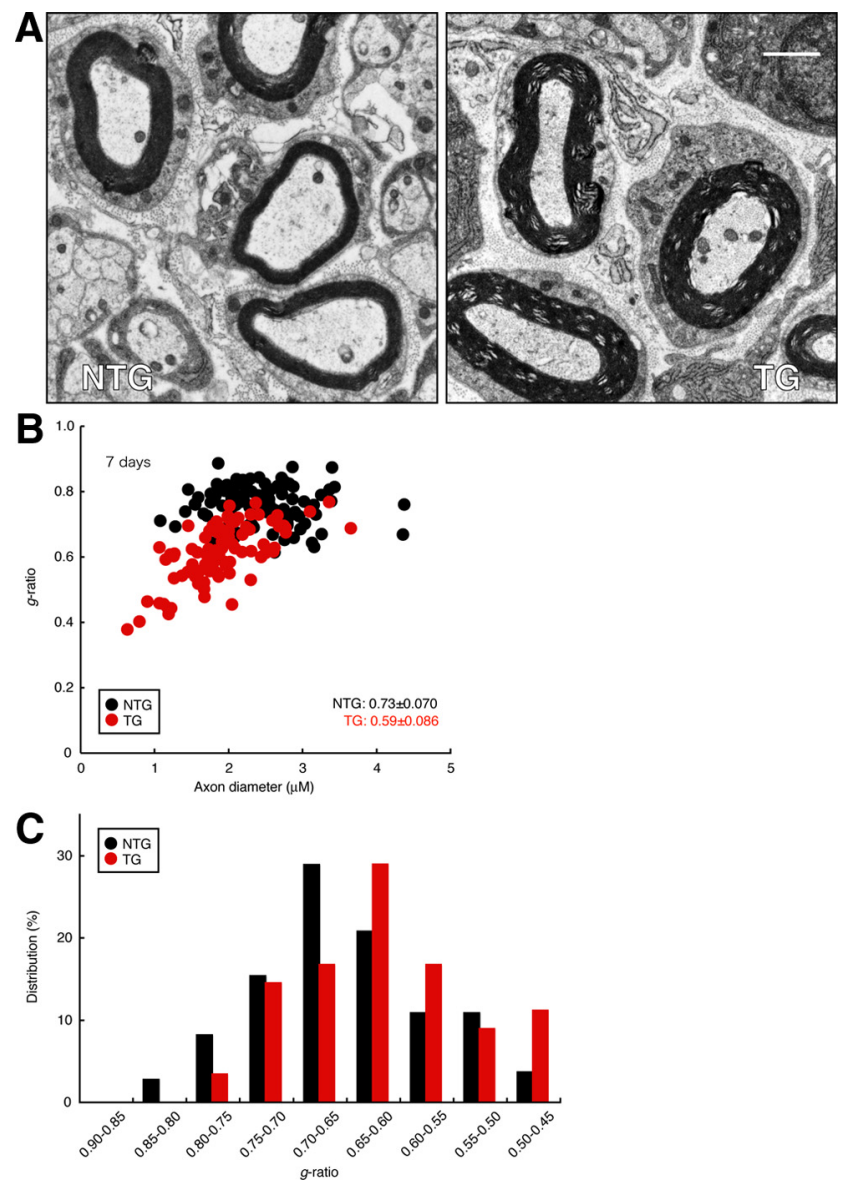

Figure 9. Dock7 knockdown in mice leads to enhanced sciatic nerve myelin thickness. $\boldsymbol{A}$, Representative electron micrograph of sciatic nerve cross-sections in a 7-d-old Dock7 shRNA transgenic mouse (TG) or a nontransgenic littermate (NTG). Scale bar, $1 \mu \mathrm{m}$. B, To obtain statistical data, we calculated the $g$-ratio, that is, the numerical ratio of the diameter of the axon proper to the outer diameter of the myelinated fiber, for each axon. When a myelinated axon has a rhomboid-like form, its diameter is calculated as the average value between the longest diameter and the shortest one. Scatter plot of the $g$-ratio derived from electron micrographs of the sciatic nerves in transgenic mice (a total of 90 nerves in two independent mice) and nontransgenic mice (a total of 114 nerves in two independent mice) for each axonal size is shown. The average $g$-ratios are also shown. $C$, Data are presented in the form of relative distribution of g-ratios.

very weakly thereafter, whereas Rho GTPases Rac1/Cdc42 exhibit stable levels of expression throughout sciatic nerve development. Schwann cells also contain other GEFs for Rho GTPases (Verhoeven et al., 2003; Hempstead, 2005; Delague et al., 2007; Stendel et al., 2007). The diversity of GEFs and/or Rho GTPase expression profiles may be one of the reasons for the phenotypic differences between Dock7 shRNA transgenic mice and Rac1 or Cdc42 knock-out mice (Benninger et al., 2007; Chan, 2007; Nodari et al., 2007). It is possible that each GEF has a particular role in Schwann cell development. Further studies on the identification of all GEFs in Schwann cells may clarify the relationship between the regulation of each GEF and the timing and duration of the activation of Racl and/or Cdc42 in Schwann cell morphogenesis.

\section{The role of Dock7 in Schwann cell differentiation and myelination}

It is clear that Dock7 knockdown negatively regulates Schwann cell differentiation and the onset of myelination, but the whole of the Dock7 signaling mechanism remains to be understood. The JNK signaling pathway negatively regulates Schwann cell differ- 


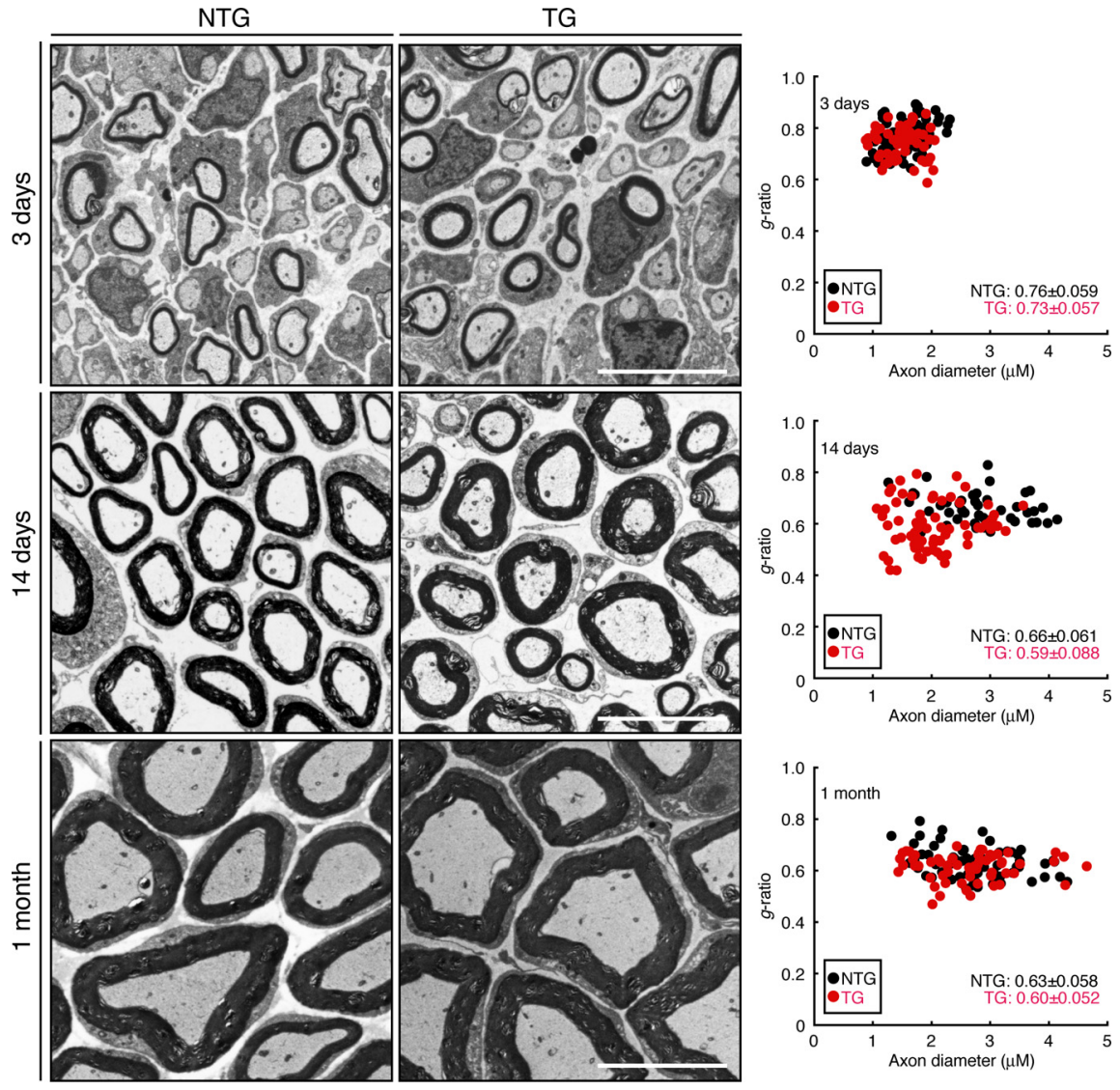

Figure 10. Electron micrographs of developing sciatic nerves. Representative electron micrographs of sciatic nerve crosssections of shRNA transgenic mice (TG) or nontransgenic littermates (NTG) at $3 \mathrm{~d}$ old, $14 \mathrm{~d}$ old, and 1 month old. Scale bar, $5 \mu \mathrm{m}$. Scatter plots of the $g$-ratio derived from electron micrographs of the sciatic nerves in transgenic mice (a total of 70,74, and 73 nerves in two independent mice at $7 \mathrm{~d}$ old, $14 \mathrm{~d}$ old, and 1 month old, respectively) and nontransgenic mice (a total of 87, 54, and 70 nerves in two independent mice at $7 \mathrm{~d}$ old, $14 \mathrm{~d}$ old, and 1 month old, respectively) for each axonal size are shown. The average $g$-ratios are also shown.

entiation and myelination (Kaempchen et al., 2003; Parkinson et al., 2004; Monje et al., 2010). Thus, one simple explanation for the observed phenomena is that the downregulation of JNK due to Dock7 knockdown causes the negative effect of Dock7 knockdown on myelination. Concomitantly, Dock7 knockdown results in the upregulation of Rho-kinase, which promotes myelination (Melendez-Vasquez et al., 2004). Because Dock7 fails to activate Rho directly, Rho/Rho-kinase may be upregulated by the imbalance of cellular Rho GTPases. Rho/Rho-kinase antagonizes Rac/ Cdc42 in many aspects of cell morphological changes (Hall, 1998; Kaibuchi et al., 1999; Bar-Sagi and Hall, 2000; Takai et al., 2001). This principle reminds us of the molecular relationship between $\mathrm{Rac} / \mathrm{Cdc} 42$ and Rho in neurotrophin regulation of Schwann cell migration. Rac/Cdc42 and JNK promote Schwann cell migration (Yamauchi et al., 2003, 2005a, 2005b), whereas Rho/Rho-kinase inhibits Schwann cell migration (Yamauchi et al., 2004). Further studies on the relationship between Rac/Cdc42 and Rho will allow us to identify GAP(s) for Rho GTPases, which participates in antagonizing Dock7 in Schwann cell differentiation and the onset of myelination, as well as migration.

Dock7 is abundantly expressed in Schwann cells, and Dock180, Dock3, Dock4, Dock5, Dock8, and Dock11 are also expressed in Schwann cells (Yamauchi et al., 2008) and in the peripheral ganglia (the UniGene website, http://www.ncbi.nlm.nih.gov/unigene/) to a greater or lesser extent. Dock180, Dock3, and Dock4 are well characterized Dock180-related proteins. These proteins may act inde- pendently on Dock7 because they primarily regulate various adhesion signals. Dock 180 specifically activates Rac in an integrindependent manner and controls the adhesion between the cell and the extracellular matrix (Kiyokawa et al., 1998). Dock3 and Dock 4 mediate the cell-cell adhesion by cadherins (Chen et al., 2005) and enhance the formation of adherens junctions (Yajnik et al., 2003), respectively. Because signaling through adhesion molecules is essential for myelination (Scherer, 2002; Colognato et al., 2005), it is conceivable that Dock180, Dock3, and Dock4 may control the adhesion signals required for myelination.

Myelination in the peripheral nervous system requires continuous interactions of peripheral neurons with Schwann cells and vice versa (Bunge, 1993; Mirsky and Jessen, 1996; Nave and Salzer, 2006). Watabe-Uchida et al. (2006) demonstrated the key role of Dock7 in hippocampal neuron development in the CNS. Dock7 contributes to hippocampal axon specification and maturation before dendrite development, showing the critical role of Dock7 in neuronal Rho GTPase signaling. In DRG neurons, Dock7 knockdown may also break the balance between Rac1/Cdc42 and Rho and may upregulate Rho signaling, which participates in secretion/exocytosis (Ridley, 1996; Sasaki, 2003). It is possible that in DRG neurons, Dock7 knockdown promotes secretion of growth factors, which are involved in myelination, thereby inducing enhanced myelin thickness. In addition, because Rho GTPases also regulate transcription and translation themselves (Hall, 1998; Kaibuchi et al., 1999; Bar-Sagi and Hall, 2000; Takai et al., 2001), Dock7 knockdown may participate in production of proteins such as growth factors. Alternatively, Rho GTPases may control the activities of membrane proteolytic processing enzymes (Tang and Liou, 2007). Although Dock7 knockdown did not alter the detectable level of neuregulin-1, it may subtly alter levels of enzyme activity and thus regulate the processing of unidentified extracellular molecules. Yet DRG neurons contain only low levels of Dock7. Thus, Dock7 may only partially participate in the regulation of myelination by Schwann cells through a signal from peripheral neurons, although it may in fact work the other way around instead. Indeed, Dock7 knockdown permits Schwann cells to myelinate more effectively both in culture and in vivo, but it may simultaneously affect the adjustment of the peripheral axon diameter. A certain signal from Schwann cells to neurons may be responsible for proper modulation of axon thickness (de Waegh et al., 1992; Sánchez et al., 1996).

\section{Regulation of Dock7 in Schwann cell differentiation and myelination}

Further studies are required to establish how Dock7 activity is strictly regulated during myelination. We previously reported that ErbB2 activates Dock7 by the direct tyrosine phosphorylation in Schwann cells (Yamauchi et al., 2008). Although phosphorylation of Dock7 is the only known regulatory mechanism 
for Dock7, Dock7 may also be regulated by other unknown mechanisms.

Dock180 forms a stable complex with two specific adaptor proteins, Src homology ( $\mathrm{SH})$ domain-only proteins such as CrkII and engulfment and cell motility (ELMO) family proteins (Matsuda and Kurata, 1996; Côté and Vuori, 2002, 2007; Meller et al., 2005; Kinchen and Ravichandran, 2007; Miyamoto and Yamauchi, 2010). The ELMOs-CrkII-Dock180 complex is needed to activate Rac along the cell periphery, leading to lamellipodial formation. The alternative method of Rac activation through Dock180 is mediated by RhoG, the other Rho GTPase. Once activated, RhoG forms a ternary complex with ELMOs-CrkII-Dock180 (Katoh and Negishi, 2003). The RhoG•GTP-ELMOsCrkII-Dock180 complex controls cell morphological changes at the cell periphery. Dock7, on the other hand, seems unlikely bind to $\mathrm{SH}$ domain-only proteins and ELMOs because it does not contain their typical binding sites (the Scansite website, http://scansite.mit.edu/).

Phosphatidylinositol-3-kinases (PI3Ks) play a key role in the early stages of myelination (Maurel and Salzer, 2000). Phosphatidylinositol-3-phosphates, the products of PI3Ks, participate in translocating Dock 180 to the plasma membranes by binding to the Dock homology region (DHR)-1 [also called CED-5, Dock180, and myoblast cityzizimin homology (CZH) 1 domain]. Dock7 may be spatially regulated by PI3Ks because DHR-1 exists in all Dock180-related proteins including Dock7.

\section{GEFs for Rho GTPases and peripheral myelin formation}

A number of mutations of the $f g d 4$ (also called frabin) gene are found in peripheral demyelinating Charcot-Marie-Tooth (CMT) neuropathy type $4 \mathrm{H}$ (CMT4H), which causes myelin outfoldings and deformed scoliosis (Delague et al., 2007; Stendel et al., 2007; Fabrizi et al., 2009; Houlden et al., 2009). FGD4 is a Dbl family GEF specific for Cdc42. FGD4 was originally identified as a $105 \mathrm{kDa}$ F-actinbinding protein and characterized as an activator of JNK (Obaishi et al., 1998). Regardless of whether FGD4 mutations in $\mathrm{CMT} 4 \mathrm{H}$ cause loss of function and/or gain of function of FGD4's cellular activities (a question that needs to be resolved), it is of interest to examine the possibility that FGD4 itself negatively regulates myelination by Schwann cells through Cdc42 and JNK. In addition, a one-point mutation in the gef10 gene (also called arhgef10) is associated with a phenotype
A
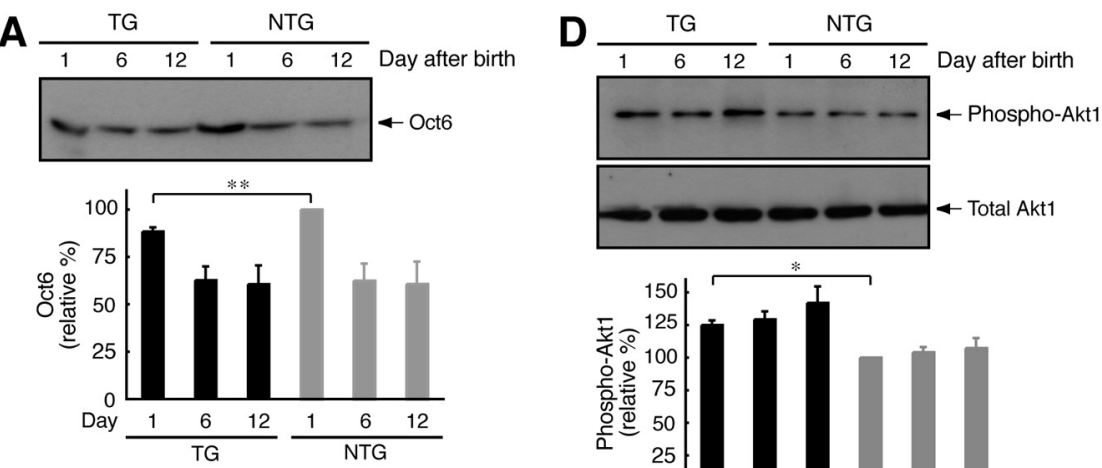

B
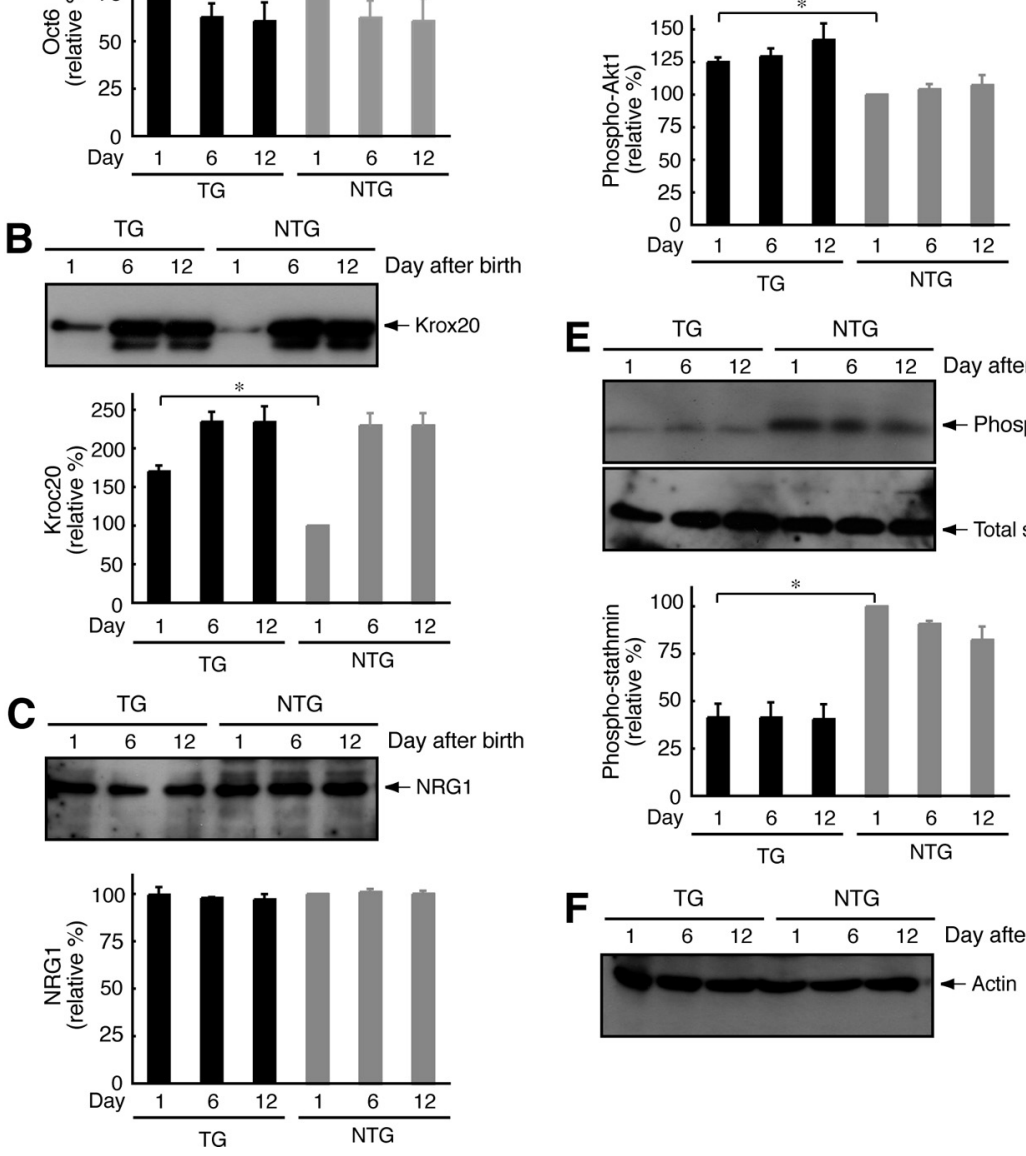

E
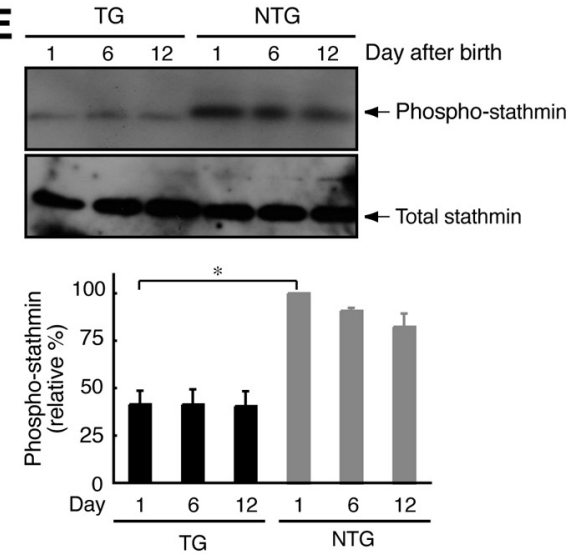

$F$

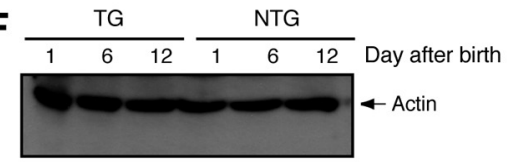

Figure 11. Effects of Dock7 knockdown in mice on signaling proteins controlling myelination. Sciatic nerve tissues at $1 \mathrm{~d}$ old, $6 \mathrm{~d}$ old, and $12 \mathrm{~d}$ old were lysed and immunoblotted with an antibody against 0 ct6 $(n=3)(\boldsymbol{A}), \operatorname{Krox20}(n=3)(\boldsymbol{B})$, neuregulin-1 $($ NRG1) $(n=3)(\boldsymbol{C}),($ pSer473)Akt1 and Akt1 $(n=3)(\boldsymbol{D}),($ pSer16)stathmin and stathmin $(n=3)(\boldsymbol{E})$, or actin $(n=3)(\boldsymbol{F})$. The active state of Akt1 is recognized with an anti-(pSer473)Akt1 antibody. Phosphorylation of stathmin at the Ser-16 position is mediated by Rac1/Cdc42 signaling. Proteins and their phosphorylation are shown as relative values. TG, Transgenic mice; NTG, nontransgenic mice. Data were evaluated using one-way ANOVA $\left({ }^{*} p<0.01 ;{ }^{* *} p<0.02\right)$.
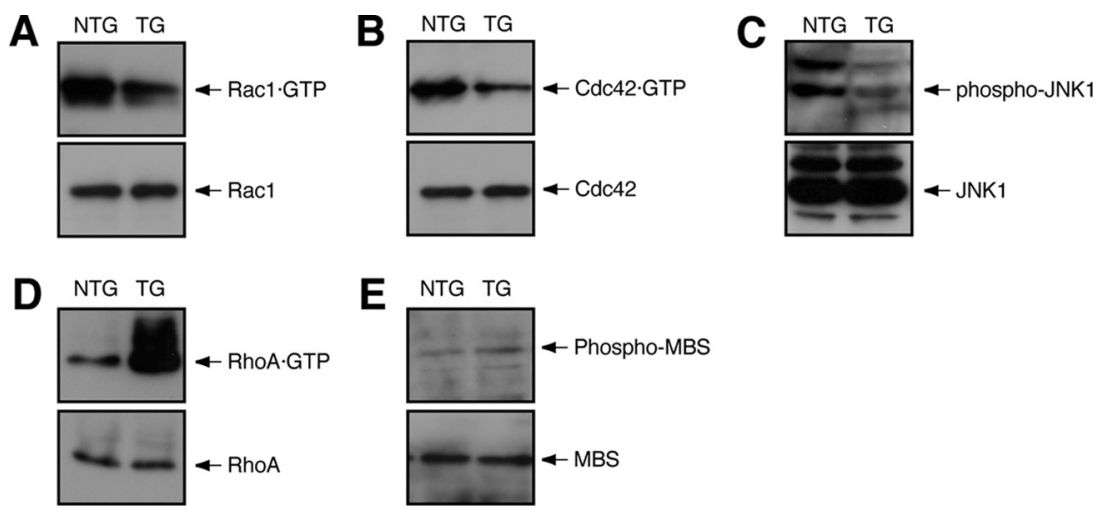

Figure 12. Dock7 knockdown in mice changes Rho GTPase signaling in sciatic nerves. $A, B, D$, Seven-day-old sciatic nerve tissues were lysed, affinity precipitated, and immunoblotted with an antibody against each small GTPase. Total small GTPase is also shown. C, Sciatic nerve tissue extracts were immunoprecipitated with an anti-JNK1 antibody and immunoblotted with an antibody against (pThr183/pTyr185)JNK. Total JNK1 is also shown. $\boldsymbol{E}$, Sciatic nerve tissue extracts were immunoblotted with an antibody against (pT853)MBS or MBS. TG, Transgenic mice; NTG, nontransgenic mice. 
exhibiting slowed nerve conduction velocities of peripheral nerves and reduced myelin thickness (Verhoeven et al., 2003). GEF10 also belongs to a Dbl family GEF but is specific for Rho (Mohl et al., 2006). Regulated activities among Rho GTPases during peripheral nerve development may play a key role in proper myelination.

In this study, we identified Dock7 as a novel regulator of Schwann cell differentiation and the onset of myelination both in vitro and in vivo. Blasius et al. (2009) reported a detailed analysis of Dock7's role in pigmentation in vivo. Mice of the mutant strain moonlight express a catalytic domain-deficient incomplete Dock7 protein, which is produced through interruption with a retrotransposon insertion, yet exhibit no apparent abnormal phenotype in terms of neurobehavioral function. The phenotypic differences between these and our transgenic mice may be due to the manner in which Dock7 is expressed: one mutation expresses mutant Dock7 and the other decreases the expression of Dock7. Alternatively, the differences may be due to a difference in mouse background. Further studies on the role and regulation of Dock7 in Schwann cells will enhance our understanding not only of the precise mechanism by which Dock7 negatively regulates the onset of myelination but also of whether Dock7 is physiologically associated with other GEFs and/or GAPs for Rho GTPases. It remains an important issue to clarify whether and/or how Dock7 is involved in the remyelination process. Such studies will help identify more suitable therapeutic targets for nerve injury, ultimately leading to the development of drug-target-specific medicines for nerve regeneration.

\section{References}

Bar-Sagi D, Hall A. (2000) Ras and Rho GTPases: a family reunion. Cell 103:227-238.

Benninger Y, Thurnherr T, Pereira JA, Krause S, Wu X, Chrostek-Grashoff A, Herzog D, Nave KA, Franklin RJ, Meijer D, Brakebusch C, Suter U, Relvas JB (2007) Essential and distinct roles for Cdc42 and Racl in the regulation of Schwann cell biology during peripheral nervous system development. J Cell Biol 177:1051-1061.

Blasius AL, Brandl K, Crozat K, Xia Y, Khovananth K, Krebs P, Smart NG, Zampolli A, Ruggeri ZM, Beutler BA (2009) Mice with mutations of Dock7 have generalized hypopigmentation and white-spotting but show normal neurological function. Proc Natl Acad Sci U S A 106:2706-2711.

Bottenstein JE, Sato GH (1979) Growth of a rat neuroblastoma cell line in serum-free supplemented medium. Proc Natl Acad Sci USA 76:514-517.

Bunge RP (1993) Expanding roles for the Schwann cell: ensheathment, myelination, trophism and regeneration. Curr Opin Neurobiol 3:805-809.

Chan JR (2007) Myelination: all about Rac 'n' roll. J Cell Biol 177:953-955.

Chan JR, Jolicoeur C, Yamauchi J, Elliott J, Fawcett JP, Ng BK, Cayouette M (2006) The polarity protein Par-3 directly interacts with p75NTR to regulate myelination. Science 314:832-836.

Chen Q, Chen TJ, Letourneau PC, Costa Lda F, Schubert D (2005) Modifier of cell adhesion regulates $\mathrm{N}$-cadherin-mediated cell-cell adhesion and neurite outgrowth. J Neurosci 25:281-290.

Colognato H, ffrench-Constant C, Feltri ML (2005) Human diseases reveal novel roles for neural laminins. Trends Neurosci 28:480-486.

Côté JF, Vuori K (2002) Identification of an evolutionarily conserved superfamily of DOCK180-related proteins with guanine nucleotide exchange activity. J Cell Sci 115:4901-4913.

Côté JF, Vuori K (2007) GEF what? Dock180 and related proteins help Rac to polarize cells in new ways. Trends Cell Biol 17:383-393.

D’Antonio M, Michalovich D, Paterson M, Droggiti A, Woodhoo A, Mirsky R, Jessen KR (2006) Gene profiling and bioinformatic analysis of Schwann cell embryonic development and myelination. Glia 53:501-515.

Daub H, Gevaert K, Vandekerckhove J, Sobel A, Hall A (2001) Rac/Cdc42 and p65PAK regulate the microtubule-destabilizing protein stathmin through phosphorylation at serine 16. J Biol Chem 276:1677-1680.

Delague V, Jacquier A, Hamadouche T, Poitelon Y, Baudot C, Boccaccio I, Chouery E, Chaouch M, Kassouri N, Jabbour R, Grid D, Mégarbané A,
Haase G, Lévy N (2007) Mutations in FGD4 encoding the Rho GDP/ GTP exchange factor FRABIN cause autosomal recessive Charcot-MarieTooth type 4H. Am J Hum Genet 81:1-16.

de Waegh SM, Lee VM, Brady ST (1992) Local modulation of neurofilament phosphorylation, axonal caliber, and slow axonal transport by myelinating Schwann cells. Cell 68:451-463.

Fabrizi GM, Taioli F, Cavallaro T, Ferrari S, Bertolasi L, Casarotto M, Rizzuto N, Deconinck T, Timmerman V, De Jonghe P (2009) Further evidence that mutations in FGD4/frabin cause Charcot-Marie-Tooth disease type 4H. Neurology 72:1160-1164.

Hall A (1998) Rho GTPases and the actin cytoskeleton. Science 279: 509-514.

Hempstead BL (2005) Coupling neurotrophins to cell migration through selective guanine nucleotide exchange factor activation. Proc Natl Acad Sci U S A 102:5645-5646.

Houlden H, Hammans S, Katifi H, Reilly MM (2009) A novel Frabin (FGD4) nonsense mutation p.R275X associated with phenotypic variability in CMT4H. Neurology 72:617-620.

Kaempchen K, Mielke K, Utermark T, Langmesser S, Hanemann CO (2003) Upregulation of the Racl/JNK signaling pathway in primary human Schwannoma cells. Hum Mol Genet 12:1211-1221.

Kaibuchi K, Kuroda S, Amano M (1999) Regulation of the cytoskeleton and cell adhesion by the Rho family GTPases in mammalian cells. Annu Rev Biochem 68:459-486.

Katoh H, Negishi M (2003) RhoG activates Racl by direct interaction with the Dock180-binding protein Elmo. Nature 424:461-464.

Kinchen JM, Ravichandran KS (2007) Journey to the grave: signaling events regulating removal of apoptotic cells. J Cell Sci 120:2143-2149.

Kiyokawa E, Hashimoto Y, Kobayashi S, Sugimura H, Kurata T, Matsuda M (1998) Activation of Rac1 by a Crk SH3-binding protein, Dock180. Genes Dev 12:3331-3336.

Matsuda Y, Chapman VM (1995) Application of fluorescence in situ hybridization in genome analysis of the mouse. Electrophoresis 16:261-272.

Matsuda M, Kurata T (1996) Emerging components of the Crk oncogene product: the first identified adaptor protein. Cell Signal 8:335-340.

Maurel P, Salzer JL (2000) Axonal regulation of Schwann cell proliferation and survival and the initial events of myelination requires PI 3-kinase activity. J Neurosci 20:4635-4645.

Melendez-Vasquez CV, Einheber S, Salzer JL (2004) Rho kinase regulates Schwann cell myelination and formation of associated axonal domains. J Neurosci 24:3953-3963.

Meller N, Merlot S, Guda C (2005) CZH proteins: a new family of RhoGEFs. J Cell Sci 118:4937-4946.

Michailov GV, Sereda MW, Brinkmann BG, Fischer TM, Haug B, Birchmeier C, Role L, Lai C, Schwab MH, Nave KA (2004) Axonal neuregulin-1 regulates myelin sheath thickness. Science 304:700-703.

Mirsky R, Jessen KR (1996) Schwann cell development, differentiation and myelination. Curr Opin Neurobiol 6:89-96.

Miyamoto Y, Yamauchi J (2010) The cellular signaling of Dock family in neural function. Cell Signal 22:175-182.

Miyamoto Y, Yamauchi J, Tanoue A, Wu C, Mobley WC (2006) TrkB binds and tyrosine-phosphorylates Tiam1, leading to activation of Rac1 and induction of changes in cellular morphology. Proc Natl Acad Sci U S A 103:10444-10449.

Mohl M, Winkler S, Wieland T, Lutz S (2006) Gef10 - the third member of a Rho-specific guanine nucleotide exchange factor subfamily with unusual protein architecture. Naunyn Schmiedebergs Arch Pharmacol 373:333-341.

Monje PV, Soto J, Bacallao K, Wood PM (2010) Schwann cell dedifferentiation is independent of mitogenic signaling and uncoupled to proliferation: role of cAMP and JNK in the maintenance of the differentiated state. J Biol Chem 285:31024-31036.

Nave KA, Salzer JL (2006) Axonal regulation of myelination by neuregulin 1. Curr Opin Neurobiol 16:492-500.

Nodari A, Zambroni D, Quattrini A, Court FA, D’Urso A, Recchia A, Tybulewicz VL, Wrabetz L, Feltri ML (2007) Betal integrin activates Rac1 in Schwann cells to generate radial lamellae during axonal sorting and myelination. J Cell Biol 177:1063-1075.

Obaishi H, Nakanishi H, Mandai K, Satoh K, Satoh A, Takahashi K, Miyahara M, Nishioka H, Takaishi K, Takai Y (1998) Frabin, a novel FGD1related actin filament-binding protein capable of changing cell shape and activating c-Jun N-terminal kinase. J Biol Chem 273:18697-18700. 
Ogata T, Iijima S, Hoshikawa S, Miura T, Yamamoto S, Oda H, Nakamura K, Tanaka S (2004) Opposing extracellular signal-regulated kinase and Akt pathways control Schwann cell myelination. J Neurosci 24:6724-6732.

Parkinson DB, Bhaskaran A, Droggiti A, Dickinson S, D'Antonio M, Mirsky R, Jessen KR (2004) Krox-20 inhibits Jun-NH2-terminal kinase/c-Jun to control Schwann cell proliferation and death. J Cell Biol 164:385-394.

Peng S, York JP, Zhang P (2006) A transgenic approach for RNA interference-based genetic screening in mice. Proc Natl Acad Sci U S A 103:2252-2256.

Ridley AJ (1996) Rho: theme and variations. Curr Biol 6:1256-1264.

Rossman KL, Der CJ, Sondek J (2005) GEF means go: turning on RHO GTPases with guanine nucleotide-exchange factors. Nat Rev Mol Cell Biol 6:167-180.

Sánchez I, Hassinger L, Paskevich PA, Shine HD, Nixon RA (1996) Oligodendroglia regulate the regional expansion of axon caliber and local accumulation of neurofilaments during development independently of myelin formation. J Neurosci 16:5095-5105.

Sasaki Y (2003) New aspects of neurotransmitter release and exocytosis: Rho-kinase-dependent myristoylated alanine-rich C-kinase substrate phosphorylation and regulation of neurofilament structure in neuronal cells. J Pharmacol Sci 93:35-40.

Scherer SS (2002) Myelination: some receptor required. J Cell Biol 156:13-15.

Schmidt A, Hall A (2002) Guanine nucleotide exchange factors for Rho GTPases: turning on the switch. Genes Dev 16:1587-1609.

Sobue G, Shuman S, Pleasure D (1986) Schwann cell responses to cyclic AMP: proliferation, change in shape, and appearance of surface galactocerebroside. Brain Res 362:23-32.

Stendel C, Roos A, Deconinck T, Pereira J, Castagner F, Niemann A, Kirschner J, Korinthenberg R, Ketelsen UP, Battaloglu E, Parman Y, Nicholson G, Ouvrier R, Seeger J, De Jonghe P, Weis J, Krüttgen A, RudnikSchöneborn S, Bergmann C, Suter U, et al. (2007) Peripheral nerve demyelination caused by a mutant Rho GTPase guanine nucleotide exchange factor, frabin/FGD4. Am J Hum Genet 81:158-164.

Takai Y, Sasaki T, Matozaki T (2001) Small GTP-binding proteins. Physiol Rev 81:153-208.
Tang BL, Liou YC (2007) Novel modulators of amyloid-beta precursor protein processing. J Neurochem 100:314-323.

Tao Y, Dai P, Liu Y, Marchetto S, Xiong WC, Borg JP, Mei L (2009) Erbin regulates NRG1 signaling and myelination. Proc Natl Acad Sci U S A 106:9477-9482.

Verhoeven K, De Jonghe P, Van de Putte T, Nelis E, Zwijsen A, Verpoorten N, De Vriendt E, Jacobs A, Van Gerwen V, Francis A, Ceuterick C, Huylebroeck D, Timmerman V (2003) Slowed conduction and thin myelination of peripheral nerves associated with mutant rho Guanine-nucleotide exchange factor 10. Am J Hum Genet 73:926-932.

Watabe-Uchida M, John KA, Janas JA, Newey SE, Van Aelst L (2006) The Rac activator DOCK7 regulates neuronal polarity through local phosphorylation of stathmin/Op18. Neuron 51:727-739.

Yajnik V, Paulding C, Sordella R, McClatchey AI, Saito M, Wahrer DC, Reynolds P, Bell DW, Lake R, van den Heuvel S, Settleman J, Haber DA (2003) DOCK4, a GTPase activator, is disrupted during tumorigenesis. Cell 112:673-684.

Yamauchi J, Tsujimoto G, Kaziro Y, Itoh H (2001) Parallel regulation of mitogen-activated protein kinase kinase 3 (MKK3) and MKK6 in Gqsignaling cascade. J Biol Chem 276:23362-23372.

Yamauchi J, Chan JR, Shooter EM (2003) Neurotrophin 3 activation of TrkC induces Schwann cell migration through the c-Jun N-terminal kinase pathway. Proc Natl Acad Sci U S A 100:14421-14426.

Yamauchi J, Chan JR, Shooter EM (2004) Neurotrophins regulate Schwann cell migration by activating divergent signaling pathways dependent on Rho GTPases. Proc Natl Acad Sci U S A 101:8774-8779.

Yamauchi J, Chan JR, Miyamoto Y, Tsujimoto G, Shooter EM (2005a) The neurotrophin-3 receptor TrkC directly phosphorylates and activates the nucleotide exchange factor Dbs to enhance Schwann cell migration. Proc Natl Acad Sci U S A 102:5198-5203.

Yamauchi J, Miyamoto Y, Tanoue A, Shooter EM, Chan JR (2005b) Ras activation of a Rac1 exchange factor, Tiam1, mediates neurotrophin-3-induced Schwann cell migration. Proc Natl Acad Sci U S A 102: 14889-14894.

Yamauchi J, Miyamoto Y, Chan JR, Tanoue A (2008) ErbB2 directly activates the exchange factor Dock7 to promote Schwann cell migration. J Cell Biol 181:351-365. 